\section{AMERICAN-EURASIAN JOURNAL OF SUSTAINABLE AGRICULTURE}

ISSN: 1995-0748, EISSN: 1998-1074

2019, Volume (13), Issue(4):pages(1-17)

DOI: 10.22587/aejsa.2019.13.4.1

Published Online in Septemberhttp://www.aensiweb.com/AEJSA/

\title{
Phosphate mineralization by a rice (Oryza sativa L.) rhizoplanic Enterobacter sp.
}

\author{
${ }^{a}$ Nilima Dash, ${ }^{a}$ Tushar Kanti Dangar \\ ${ }^{a}$ Microbiology Laboratory, Division of Crop Production, National Rice Research Institute, Cuttack, Odisha, India
}

Received date: 12 July 2019, Accepted date: 1 December 2019, Online date: 5 December 2019

Address for Correspondence:

Tushar Kanti Dangar, Microbiology Laboratory, Division of Crop Production, National Rice Research Institute, Cuttack, Odisha, India E-mail: tkdangar@gmail.com

Copyright $\odot 2019$ by authors and American-Eurasian Network for Scientific Information. This work is licensed under the Creative Commons Attribution International License (CC BY). http://creativecommons.org/licenses/by/4.0/

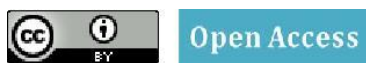

\begin{abstract}
Rhizoplane is the hotspot of plant microbe interaction where various plant growth promoting bacteria convert insoluble phosphatic compounds into accessible form for plants; thereby enhance plant health and productivity. An efficient rhizoplanic plant growth promoting Enterobacter sp. R1 of rice $(O$. sativa $L$.) cv. Swarna Sub-I was thoroughly studied which mineralized Ca-phosphate $(574.7 \mu \mathrm{g} / \mathrm{ml})$, Zn phosphate, rock phosphates and slag and also tolerated 9\% NaCl. Besides P-solubilization (PS), it produced indole, siderophore $(66.35 \mathrm{mg} / \mathrm{g} \mathrm{dr}$. wt.) and ammonia which would promote growth of plants. The bacterium mineralized $P$ by acid $(22.25 \mathrm{U} / \mathrm{ml})$ and alkaline phosphatase $(76.37 \mathrm{U} / \mathrm{ml})$ and organic acid (citric acid, lactic acid, tartaric acid etc.) production. R1 challenged plants had enhanced root $(66.67 \%)$ and shoot $(28.81 \%)$ length in the laboratory test, and augmented growth and production in pot and field conditions. The bacterium intrinsically possessed the $\mathrm{P}$ solubilizing $\mathrm{pqq} \mathrm{C}$ gene. Multiple plant growth promoting (PGP) traits and salt tolerance rendered the organism to be potent for biofertilizer production suitable for both non-saline and saline environments.
\end{abstract}

\section{KEYWORDS}

Enterobacter, phosphate solubilization, plant growth promotion, rhizoplane, rice

\section{INTRODUCTION}

Limitation of available phosphorus in soil necessitates regular supplement of chemical P fertilizer to plants which causes biological and environmental hazards like ground water contamination, eutrophication, hypoxia in aqua pools etc. Eco-friendly phosphate solubilizing microbes (PSM) would partially substitute chemical Pfertilizers through biogeochemical cycling of different insoluble P (IP) compounds and make available to rice and other plants [1]. The PSM mineralize IP compounds through acidification by organic/inorganic acid and phosphatase production, ion exchange reactions, chelation etc. Co-application of polyvalent PSM and rock phosphates in soil effected release of phosphorus, promotion of plant growth, improvement of soil texture, suppression of plant pathogens etc. and made it a promising, cheaper and ecofriendly growth promoter [2]. $\mathrm{P}$ is essential for different metabolic pathways and energy metabolism in plants which promotes tillering, root development, early flowering, ripening (especially at low temperature) etc. It increases straw strength, maintains membrane integrity, resists diseases, particularly at early stages of rice growth [1]. The phosphate solubilizing bacteria (PSB) would help to increase P uptake by grain and straw of rice [3].

Oxidation of glucose is correlated with microbial P metabolism. Glucose dehydrogenase (GDH) oxidizes glucose to gluconic acid through direct oxidation (DO) pathway supported by the redox cofactor pyrroloquinoline quinone (PQQ) and $\mathrm{Ca}^{2+}\left(\right.$ or $\left.\mathrm{Mg}^{2+}\right)$ followed by 2-keto gluconic acid and 2, 5-di-keto gluconic acid by gluconate dehydrogenase [4]. The PQQ metabolic enzyme was revealed to be a cluster of six open 
reading frames (orf) (pqqA, B, C, D, E, F) and have been cloned from Klebsiella pneumoniae and Rahnella aquatilis [5].

On rhizoplane (root surface), PSM firmly attach by flagella, fimbriae or cell surface polysaccharides, maintain neutral $\mathrm{pH}$ and release P [6]. Evidently, Acinetobacter sp. BR-25 with higher phosphate solubilizing activity $(387 \mu \mathrm{g} / \mathrm{ml})$ recorded dense colonization on root surfaces of rice [7]. However, information of P-mineralization by rice rhizoplanic bacteria is limited and no mineralizer has been thoroughly evaluated.

Therefore, PS activity potency of a rhizoplanic bacterium and its effect on growth of rice plants in laboratory, pot culture in net house and field conditions were worked out.

\section{Experimental site, soil properties and rice cultural practices}

The rice (Oryza sativa L.) cv. Swarna Sub-I, Anjali, Ajay and Naveen were grown in sandy loam soil (Table 1) in NRRI, Cuttack for isolation of phosphate solubilizing bacteria (PSB). Rice cv. Naveen was used to check efficiency of the PSB on promotion of growth in laboratory, net house and field conditions, transplanted with 1 $(15 \mathrm{~d}$ old $)$ seedling/spot in 3 replications at $15 \times 20 \mathrm{~cm}$ spacing between plants and rows, respectively. The agronomic practices used for field and pot tests were amendment of 5t/ha farm yard manure and fertilization with 120:60:60=N:P:K or 90:45:45=N:P:K in rabi (dry, February-June) and kharif (wet, August-December) seasons, respectively.

\section{Collection of plant samples}

Rice cv. Swarna Sub-I, Anjali, Ajay and Naveen plant samples were collected from the field, roots were washed thoroughly successively with tap water and distilled water, cut into $1 \mathrm{~cm}$ long pieces, washed repeatedly with sterile (autoclaved at $121^{\circ} \mathrm{C}, 15 \mathrm{~min}$ as a general practice unless otherwise mentioned elsewhere) distilled water and a few root pieces were used for gravimetric dr. wt. estimation.

\section{Isolation of phosphate solubilizing rhizoplanic bacteria}

Five thoroughly washed (soil free) root pieces were suspended in $10 \mathrm{ml}$ sterile wash solution $(0.001 \%$ tween 80 , $0.01 \mathrm{M} \mathrm{MgSO}_{4}$ and $0.15 \%$ glycerol) and shaken at $30 \pm 0.1^{\circ} \mathrm{C}$ at $80 \mathrm{rpm}$ for $12 \mathrm{~h}$. The roots were recovered from the flask, washed thoroughly with sterile distilled water and blotted to dryness within sterile filter papers. Longitudinal half portion of the roots were kept pressed on sterile nutrient agar (NA) (g/l: peptone 5, beef extract 3, $\mathrm{NaCl} 5$, agar 18, pH 7) plates and incubated for $2 \mathrm{~h}$ at $30 \pm 0.1^{\circ} \mathrm{C}$. Similarly, the reverse sides of the roots were also incubated for $2 \mathrm{~h}$ on a different place of the medium and then removed. The plates were incubated for $2 \mathrm{~d}$ at $30 \pm 0.1^{\circ} \mathrm{C}$. The bacterial clumps of root impression were washed with $5 \mathrm{ml}$ sterile distilled water, diluted up to $10^{-3}$ level, $100 \mu$ diluted suspension was mixed with $100 \mathrm{ml}$ NA and plated in 5 plates. Dissimilar colonies were picked up, purified by dilution streaking and pure colonies were isolated. The isolated bacteria were spotted on sterile National Botanical Research Institute Phosphate (NBRIP) medium (g/l: glucose $10, \mathrm{Ca}_{3}\left(\mathrm{PO}_{4}\right)_{2} 5, \mathrm{MgCl}_{2} \cdot 6 \mathrm{H}_{2} \mathrm{O} 5, \mathrm{MgSO}_{4} \cdot 7 \mathrm{H}_{2} \mathrm{O} 0.25, \mathrm{KCl} 0.2,\left(\mathrm{NH}_{4}\right)_{2} \mathrm{SO}_{4} 0.1$, agar 18, pH 7) and colonies with halozone were picked up as $\mathrm{P}$ solubilizers $(\mathrm{n}=20)$. The selected rhizoplanic isolates were purified, subcultured and preserved on NA slants at $4 \pm 0.1^{\circ} \mathrm{C}$ and in $15 \%$ glycerol at $-80^{\circ} \mathrm{C}$. A P-solubilizing bacterium was isolated from a commercial biofertilizer for comparative analysis with the native PSB.

\section{Characterization and identification of the rhizoplanic PSB R1}

Cultural, morphological, physiological and biochemical characters, growth with 1 to $10 \% \mathrm{NaCl}$, extracellular enzyme production, response to different antibiotics etc. of the potent P solubilizer (R1) were studied following standard methods and phenotyped according to bacterial systematics propositions $[8,9]$.

\section{S rDNA sequence analysis of the rhizoplanic PSB R1}

Genomic DNA (gDNA) was extracted from $24 \mathrm{~h}$ old washed bacterial pellet (centrifuged at $10000 \mathrm{rpm}$, $4 \pm 0.1^{\circ} \mathrm{C}, 10 \mathrm{~min}$ as a general practice unless otherwise mentioned elsewhere) from nutrient broth (NB) culture. The 16S rDNA fragment of gDNA was amplified in $25 \mu \mathrm{l}$ reaction mixture containing $1 \mathrm{X}$ buffer, $100 \mu \mathrm{M}$ dNTP, $10 \mu \mathrm{M}$ forward and reverse primers (27F-5'AGAGTTTGATCCTGGCTCAG3' and 1495R5'AAGGAGGTGATCCAGCCGCA3'), $1 \mathrm{U}$ Taq polymerase and $1 \mu 1$ (20 ng) gDNA through PCR programme of initial denaturation at $95^{\circ} \mathrm{C}$ for $5 \mathrm{~min}$, followed by $30 \mathrm{cycles}$ each at $95^{\circ} \mathrm{C}$ for $30 \mathrm{sec}, 55^{\circ} \mathrm{C}$ for $30 \mathrm{sec}$ and $72^{\circ} \mathrm{C}$ for $2 \mathrm{~min}$, final extension at $72^{\circ} \mathrm{C}$ for $10 \mathrm{~min}$ and lastly at $4^{\circ} \mathrm{C}$ for $10 \mathrm{~min}$. The PCR product was resolved in $1 \%$ agarose gel electrophoresis (AGE), about $1.5 \mathrm{kbp}$ band was extracted from gel using QiaGen PCR purification kit, sequenced through service providers (Excelris, India). The 16S rDNA sequence was submitted to NCBI GenBank (KY921886). 
Nilima Dash, Tushar Kanti Dangar., 2019. Phosphate mineralization by a rice (Oryza sativa L.) rhizoplanic Enterobacter sp./American-Eurasian Journal of Sustainable Agriculture. 13(4): 1-17.DOI: 10.22587/aejsa.2019.13.4.1

Qualitative and quantitative estimation of phosphate solubilization by different rhizoplanic bacteria The rhizoplanic isolates were spotted on NBRIP plates, incubated for $3 \mathrm{~d}$ at $30 \pm 0.1^{\circ} \mathrm{C}$ and $\mathrm{P}$ solubilization index (PSI) was calculated from the ratio of the diameter of clear zones and the bacterial colonies. $\mathrm{PSI}=(\mathrm{Z}+\mathrm{C}) / \mathrm{C}$, where, $\mathrm{Z}$ is diameter of cleared zone and $\mathrm{C}$ is diameter of colony [10].

Quantity of inorganic phosphate $\left(\mathrm{Ca}_{3}\left(\mathrm{PO}_{4}\right)_{2}\right)$ solubilization in $20 \mathrm{ml}$ NBRIP broth was estimated at $24 \mathrm{~h}$ intervals up to $3 \mathrm{~d}$ in shake $(80 \mathrm{rpm})$ cultures at $30 \pm 0.1{ }^{\circ} \mathrm{C}$. The broth was centrifuged, to $1 \mathrm{ml}$ culture supernatant, $2 \mathrm{ml}$ sulfo-molybdate reagent $(2.5 \%$ sulfomolybdate solution), $0.1 \mathrm{ml} 0.25 \%$ p-nitro phenol indicator, $0.2 \mathrm{ml} 1 \mathrm{~N} \mathrm{H}_{2} \mathrm{SO}_{4}$ and $1 \mathrm{ml}$ stannous chloride solution $(40 \% \mathrm{w} / \mathrm{v}$ in $\mathrm{HCl})$ were added, $\mathrm{A} 660 \mathrm{~nm}$ was recorded [11] and soluble $\mathrm{P}(\mu \mathrm{g} / \mathrm{ml})$ was estimated. According to best $\mathrm{P}$ solubilization efficiency, one bacterium (R1) was selected for further studies.

For qualitative organic phosphate (phytate) mineralization, phytate screening medium (g/l: D-glucose 10 , sodium phytate $4, \mathrm{CaCl}_{2} .2 \mathrm{H}_{2} \mathrm{O} 2, \mathrm{NH}_{4} \mathrm{NO}_{3} 5, \mathrm{KCl} 0.5, \mathrm{MgSO}_{4} .7 \mathrm{H}_{2} \mathrm{O} 0.5, \mathrm{MnSO}_{4} \cdot \mathrm{H}_{2} \mathrm{O} 0.01, \mathrm{FeSO}_{4} .7 \mathrm{H}_{2} \mathrm{O} 0.01$, agar 15, pH 7) was inoculated and incubated [12]. Clear zone around the colonies of organisms was considered positive for phytate mineralization. Free inositol in phytate broth culture was quantified to assess inorganic phosphate solubilization.

\section{Assessment of plant growth promoting traits of the rhizoplanic PSB R1}

To $1 \mathrm{ml}$ broth (g/l: peptone $20, \mathrm{NaCl} 5$ and tryptophan $0.1 \%, \mathrm{pH} 7)$ culture $\left(3 \mathrm{~d} \mathrm{at} 30 \pm 0.1^{\circ} \mathrm{C}\right)$ of $\mathrm{R} 1,1 \mathrm{ml}$ Salkowski reagent $\left(50 \mathrm{ml} 35 \% \mathrm{HClO}_{4}\right.$ containing $\left.0.5 \mathrm{M} \mathrm{FeCl}_{3}\right)$ was mixed and change of medium to pink colour indicated indole production [13]. The isolate was spotted and grown $\left(30 \pm 0.1^{\circ} \mathrm{C}, 5-6 \mathrm{~d}\right)$ on Chromeazurol $\mathrm{S}$ (CAS) agar medium $(50 \mathrm{ml}$ solution A (chromazurol $60.6 \mathrm{mg}$ in $50 \mathrm{ml}$ water), $10 \mathrm{ml}$ solution B (1 mM $\mathrm{FeCl}_{3} \cdot \mathrm{H}_{2} \mathrm{O}$ in $\left.10 \mathrm{mMHCl}\right), 40 \mathrm{ml}$ solution $\mathrm{C}(\mathrm{CTAB} 72.9 \mathrm{mg}$ in $40 \mathrm{ml}$ water) and $300 \mathrm{ml} \mathrm{NA})$ and yellow to orange zone formation against blue background proved siderophore production [14]. To quantify siderophore in NB culture (grown at $30 \pm 0.1^{\circ} \mathrm{C}, 3 \mathrm{~d}$ ), $6 \mathrm{ml}$ bacteria-free centrifuged culture supernatant was adjusted to $\mathrm{pH} 2$ with $\mathrm{HCl}$, siderophore was extracted 3 times each with equal volume ethyl acetate. To $5 \mathrm{ml}$ pooled extract, $5 \mathrm{ml}$ Hathway's reagent $\left(1 \mathrm{ml} 0.1 \mathrm{M} \mathrm{FeCl}_{3}\right.$ in $0.1 \mathrm{~N} \mathrm{HCl}$ mixed with $100 \mathrm{ml}$ distilled water and $1 \mathrm{ml} 0.1 \mathrm{M}$ potassium ferricyanide) was mixed, colour of aqueous phase was read A650 nm and siderophore was quantified as dihydroxy benzoic acid equivalent [15]. To five ml peptone water ( $\mathrm{g} / \mathrm{l}$ : peptone $10, \mathrm{NaCl} 5)$ culture $(96 \mathrm{~h}$ at $30 \pm$ $0.1^{\circ} \mathrm{C}$ ) of $\mathrm{R} 1,0.5 \mathrm{ml}$ Nessler's reagent $\left(70.83 \mathrm{~g} / 1 \mathrm{~K}_{2} \mathrm{HgI}_{4}\right.$ in $\left.2.5 \mathrm{M} \mathrm{KOH}\right)$ was mixed and brown colouration indicated $\mathrm{NH}_{3}$ production [16].

\section{Mineralization of different phosphates by the rhizoplanic PSB R1}

Different rock phosphates viz. North Carolina (12.81\% P), Gafsa (12.007\% P), Tenesse (12.09\% P), Morocco $(14.61 \% \mathrm{P})$ and Florida $(14.22 \% \mathrm{P})$ of particle sizes of 100 mesh, sodium phytate, zinc phosphate $\left(\mathrm{Zn}_{3}\left(\mathrm{PO}_{4}\right)_{2}\right)$ and slag $(0.76 \% \mathrm{P})$ were assessed along with change of $\mathrm{pH}$ of the medium [11].

\section{Analysis of pqq gene of the rhizoplanic PSB R1}

The $p q q \mathrm{C}$ gene of $\mathrm{R} 1 \mathrm{gDNA}$ was amplified [17] in $25 \mu \mathrm{l}$ reaction mixture $(5 \mu 110 \mathrm{X}$ buffer, $2 \mu \mathrm{ldNTP}(2 \mathrm{mM})$, $0.5 \mu \mathrm{l}$ each of forward pqqCf1 (5'CAGGGCTGGGTCGCCAACC3') and reverse pqqCr1 (5'CATGGCATCGAGCATGCTCC3') primers (give stock conc.), $0.3 \mu$ TTaq DNA polymerase (500U) and sterile water $15.7 \mu \mathrm{l}$ ) through the PCR protocol of initial denaturation at $95^{\circ} \mathrm{C}$ for 5 min once, followed by 30 cycles each at $95^{\circ} \mathrm{C}$ for $30 \mathrm{sec}, 64^{\circ} \mathrm{C}$ for $45 \mathrm{sec}$ and $72^{\circ} \mathrm{C}$ for $1.5 \mathrm{~min}$ and final elongation at $72^{\circ} \mathrm{C}$ for $7 \mathrm{~min}$. PCR products were resolved in 1.2\% AGE, 546 bp band was purified using relevant kit, amplicons were sequenced through outsourcing (SciGenome, India) and the $p q q \mathrm{C}$ sequence was submitted to NCBI GenBank (MH221197).

\section{Production of acid and alkaline phosphatases by the rhizoplanic PSB R1}

To assay acid and alkaline phosphatases [18], the bacterium (R1) was cultured $\left(3 \mathrm{~d}, 30 \pm 0.1^{\circ} \mathrm{C}, 85 \mathrm{rpm}\right)$ in 20 $\mathrm{ml}$ NBRIP broth, samples were withdrawn at $24 \mathrm{~h}$ intervals and centrifuged. To $1 \mathrm{ml}$ bacteria-free supernatant, $0.2 \mathrm{ml}$ toluene, $4 \mathrm{ml}$ modified universal buffer (MUB) $(12.1 \mathrm{~g}$ tris, $11.6 \mathrm{~g}$ maleic acid, $14 \mathrm{~g}$ citric acid, $6.3 \mathrm{~g}$ boric acid and $488 \mathrm{ml} 1 \mathrm{~N} \mathrm{NaOH}$ and volume made to 11 with water, $\mathrm{pH} 6.5$ for acid phosphatase and $\mathrm{pH} 11$ for alkaline phosphatase) and $1 \mathrm{ml} \mathrm{p-nitrophenyl} \mathrm{phosphate} \mathrm{solution}(0.025 \mathrm{M})$ were mixed, incubated at $37 \pm 0.1^{\circ} \mathrm{C}$ for $1 \mathrm{~h}$, and $1 \mathrm{ml} 0.5 \mathrm{M} \mathrm{CaCl}_{2}$ and $4 \mathrm{ml} 0.5 \mathrm{M} \mathrm{NaOH}$ were mixed, filtered and $\mathrm{A} 420 \mathrm{~nm}$ was recorded, reaction product was estimated as p-nitrophenol equivalents and expressed as phosphatase units i.e. amount of enzyme that released $1 \mu \mathrm{mol}$ of $p$-nitrophenol $/ \mathrm{ml} / \mathrm{min}$ from di-Na $p$-nitrophenyl phosphate.

Separation, identification and quantification of organic acids produced by the rhizoplanic PSB R1 
Nilima Dash, Tushar Kanti Dangar., 2019. Phosphate mineralization by a rice (Oryza sativa L.) rhizoplanic Enterobacter sp./American-Eurasian Journal of Sustainable Agriculture. 13(4): 1-17.DOI: 10.22587/aejsa.2019.13.4.1

Organic acids $(\mathrm{OA})$ of P-solubilization broth culture $\left(3 \mathrm{~d}, 30 \pm 0.1^{\circ} \mathrm{C}\right)$ were extracted in ethyl acetate, air dried, residue was revived in $0.5 \mathrm{ml}$ methanol and partitioned by thin layer chromatography (TLC) on silica gel G (1 $\mathrm{mm}$ thickness) developed in ethanol:ammoniumhydroxide:water (75.5:12.5:12, by volume) solvent system in ascending position along with authentic OAs [19]. The metabolized OAs were visualized as yellow spots after spraying $0.4 \%(\mathrm{w} / \mathrm{v})$ ethanolic bromocresol green containing $0.1 \mathrm{~N} \mathrm{NaOH}$ and identified by comparing the retention factor ( $R f)\left(R f=d_{A} / d_{F}\right.$, where, $d_{A}$ is the distance ascended by organic acid, and, $d_{F}$, the distance ascended by the solvent).

OAs were identified and quantified also through HPLC-PDA system with C18 column [20]. NBRIP broth culture of R1 was centrifuged, supernatant was filtered $(0.22 \mu \mathrm{M}$ filter) and run through HPLC with mobile phase $0.1 \%$ TFA $(\mathrm{pH} 3)$ in water:methanol= $(95: 5, \mathrm{v} / \mathrm{v})$, injecting $20 \mu \mathrm{l} \mathrm{sample}$ with flow rate $0.8 \mathrm{ml} / \mathrm{min}$. The OA peaks were detected at $210 \mathrm{~nm}$ with PDA detector and quantified from calibration curves.

\section{Effect of preservatives on survivability of the rhizoplanic PSB R1 (Enterobacter sp.)}

Survivability of R1 was checked up to $100 \mathrm{~d}$ in presence of individual and combination of different preservatives viz. citric acid (0-0.1\%), sodium benzoate (0-0.2\%), formaldehyde (0-0.003\%) and glycerol (0-0.1\%).

\section{Effect of the rhizoplanic PSB R1 on growth of rice seedlings in laboratory}

Six surface sterilized (in $0.01 \% \mathrm{HgCl}_{2}, 3 \mathrm{~min}$ ) and washed (3 times in sterile water) seeds of cv. Naveen were challenged with $2.13 \times 10^{7} \mathrm{cfu} / \mathrm{ml} \mathrm{R} 1$ suspension for $12 \mathrm{~h}$ in a petriplate lined with sterile and wet filter paper. Excess inoculum was blotted; seeds were put in another sterile petriplate, incubated in darkness at $30 \pm 0.1^{\circ} \mathrm{C}$ for $2 \mathrm{~d}$ for germination and subsequently under sunlight for 5 more days. Number of roots, root and shoot lengths, fr. and dr. wt. of root and shoot of the treated and untreated seedlings were recorded.

Effects of the rhizoplanic PSB R1 and a commercial P solubilizer on growth of rice seedlings grown on sterile soil in laboratory

Sterile rice seeds were germinated on sterile soil in trays and the seedlings were uprooted after $10 \mathrm{~d}$, washed with sterile tap water followed by sterile distilled water, treated with $1.67 \times 10^{7} \mathrm{cfu} / \mathrm{ml}$ bacteria in NB for $12 \mathrm{~h}$. Two treated/untreated seedlings were transplanted in each $25 \times 9 \mathrm{~cm}$ (h x dia.) tall glass beakers with sterile soil (autoclaved at $1.1 \mathrm{~kg} / \mathrm{cm}^{2}, 1 \mathrm{~h}, 3 \mathrm{~d}$ ), grown for $20 \mathrm{~d}$, watered with sterile water as and when required and growth indices were recorded.

\section{Effect of the rhizoplanic PSB R1 on growth of rice in pot culture in net house}

Plastic pots $(20 \mathrm{~cm}$ top dia. x $10 \mathrm{~cm} \mathrm{~h}$ ) were cleaned sequentially with $1 \%$ teepol, $50 \%$ (w/v) bleaching powder, sterile water and dried under sun, then washed with $30 \%$ formaldehyde, dried and filled with $3.5 \mathrm{~kg}$ sterile, dry, 200 mesh soil (Table 1) keeping $5 \mathrm{~cm}$ empty top space. Surface sterilized Naveen seeds soaked overnight in sterile water were grown on sterile moist soil (Table 1) on a tray for 10d. The seedlings were uprooted, washed thoroughly with tap water followed by sterile water, treated with $500 \mathrm{ml}\left(2.4 \times 10^{8}\right.$ cells $\left./ \mathrm{ml}\right) \mathrm{NB}$ culture (O.D. 1) of Enterobacter sp. R1 and two seedlings were planted in pots. The pots were placed in a randomized design and fertilized with recommended dose of fertilizers (RDF) viz. 120:60:60 =N:P:K kg/ha. The first dose of fertilizer was applied after 15d. Urea was applied in three equal splits, 3-5 cm standing water in pots and growth parameters were recorded after $30 \mathrm{~d}$ and at harvest. The treatments were:

T1- Control without fertilizer

T2- RDF of N:P:K

T3- N: 1/2P: $\mathrm{K}$ according to RDF

T4- Only bacteria (R1)

T5- Bacteria (R1) + N:1/2P:K according to RDF

Table 1: Physical and chemical characteristics of experimental rice field and pot soil

\begin{tabular}{|c|c|c|}
\hline Characteristics & Pot soil & Field soil \\
\hline Textural class & Sandy loam & Sandy loam \\
\hline $\mathrm{pH}$ & 6.53 & 6.06 \\
\hline E.C. $(\mathrm{S} / \mathrm{m})$ & 0.09 & 0.06 \\
\hline Organic carbon $(\%)$ & 1.04 & 1.56 \\
\hline Total N (kg/ha) & 470.4 & 314.85 \\
\hline Available P(kg/ha) & 9.00 & 3.00 \\
\hline Exchangeable K $(\mathrm{kg} / \mathrm{ha})$ & 166.9 & 129.6 \\
\hline
\end{tabular}

Effect of the rhizoplanic PSB R1 for growth of rice in field 
In rabi (dry) and kharif (wet) seasons, 4 x $4 \mathrm{~m}$ randomized plots were taken for experiments. The $21 \mathrm{~d}$ old Naveen seedlings were uprooted, washed thoroughly with tap water followed by sterile water, treated overnight in trays with 3 litres of $2.8 \times 10^{8}$ cells/ml NB culture (O.D. 1) of Enterobacter sp. R1. The control seedlings were dipped in sterile water overnight. The plots were transplanted with single seedling at each spot (hill). Spacing between hill $\times$ rows were $15 \times 15 \mathrm{~cm}$ (rabi) and $20 \times 20 \mathrm{~cm}$ (kharif) with three replications in randomized block design and rice plants were fertilized with RDF viz. 120:60:60 and 90:45:45 N:P:K kg/ha for rabi and kharif seasons, respectively.

The treatments were:

T1- Control without any fertilizer

T2- RDF of N:P:K

T3- N: $1 / 2 \mathrm{P}: \mathrm{K}$ according to RDF

T4- Bacteria + N:1/2P:K according to RDF

T5- Only bacteria

T6- N+K (according to RDF)

Growth parameters viz. plant height $(\mathrm{cm})$, tiller (no.), panicle length $(\mathrm{cm})$ and leaf area $(\mathrm{sq} . \mathrm{cm})$ were measured prior to harvest and root length $(\mathrm{cm})$, root fr. wt. $(\mathrm{g})$, root dr. wt. $(\mathrm{g})$, panicle weight $(\mathrm{g})$, grain yield/plant $(\mathrm{g})$ and 1000 grain wt. (g) at $20 \%$ moisture level were recorded on $145 \mathrm{~d}$ after harvest. Chlorophyll a and b contents were measured from flag leaf at panicle initiation (PI, $110 \mathrm{~d}$ ) stage. Fresh leaves (100 mg) were dipped in $20 \mathrm{ml} 80 \%$ aqueous acetone, preserved at $4 \pm 0.1^{\circ} \mathrm{C}$ for $24 \mathrm{~h}$ and $\mathrm{A} 645 \mathrm{~nm}$ and $\mathrm{A} 663 \mathrm{~nm}$ were recorded to estimate chlorophyll a and b contents [21].

\section{RESULTS}

\section{Characterization and identification of the rhizoplanic PSB R1}

The rhizoplanic bacterium R1 (isolated from Swarna Sub-I) was Gram negative, non-spore forming and motile rod. The colonies were circular, white, convex, entire, 2-3 mm dia. and gummy. The organism measured (2.0$3.0 \mu \mathrm{m}) \times(1.0-1.5 \mu \mathrm{m}) 1 \times \mathrm{w}, \mathrm{H}_{2} \mathrm{~S}$ production, methyl red, urease, oxidase and arginine dihydrolase negative but catalase, VP, citrate utilization, nitrate reduction and indole production positive; oxidized and fermented glucose and lactose. The slant and butt of culture tubes became yellow and produced hydrogen in triple sugar iron test. The organism was resistant to ampicillin, ketoconazole, nystatin, penicillin $G$ and vancomycin but sensitive to azithromycin, chloramphenicol, erythromycin, gentamycin, kanamycin, nalidixic acid, neomycin, streptomycin, tetracycline and rifampicin. It hydrolyzed tween 80 and tributyrin but did not produce amylase, protease, pectinase, cellulase, DNase and lecithinase and tolerated up to $9 \% \mathrm{NaCl}$. The 16S rDNA sequence of the organism was checked for similarities in NCBI Blast and EZBioCloud database, which showed 99\% homology to Enterobacter sp. The culture was submitted to NCCS, Pune (MCC 3473) and 16S rDNA sequence to NCBI (KY921886).

\section{Inorganic and organic phosphate solubilization by the rhizoplanic PSB R1}

Enterobacter sp. (R1) solubilized maximum $\mathrm{P}(574.7 \mu \mathrm{g} / \mathrm{ml})$, lowered medium pH to 4.04 in $2 \mathrm{~d}$ (Fig. 1) and produced PGP factors like indole, ammonia and siderophore $(66.35 \mathrm{mg} / \mathrm{g} \mathrm{dr}$. wt.). Besides, R1 solubilized zinc phosphate $(434.1 \mu \mathrm{g} / \mathrm{ml})$ with lowering to medium $\mathrm{pH} 5.1$ and $84.52 \mu \mathrm{g} / \mathrm{ml}$ organic phosphate (sodium phytate) lowering to $\mathrm{pH} 4.51$ (Fig. 2). 
Nilima Dash, Tushar Kanti Dangar., 2019. Phosphate mineralization by a rice (Oryza sativa L.) rhizoplanic Enterobacter sp./American-Eurasian Journal of Sustainable Agriculture. 13(4): 1-17.DOI: 10.22587/aejsa.2019.13.4.1

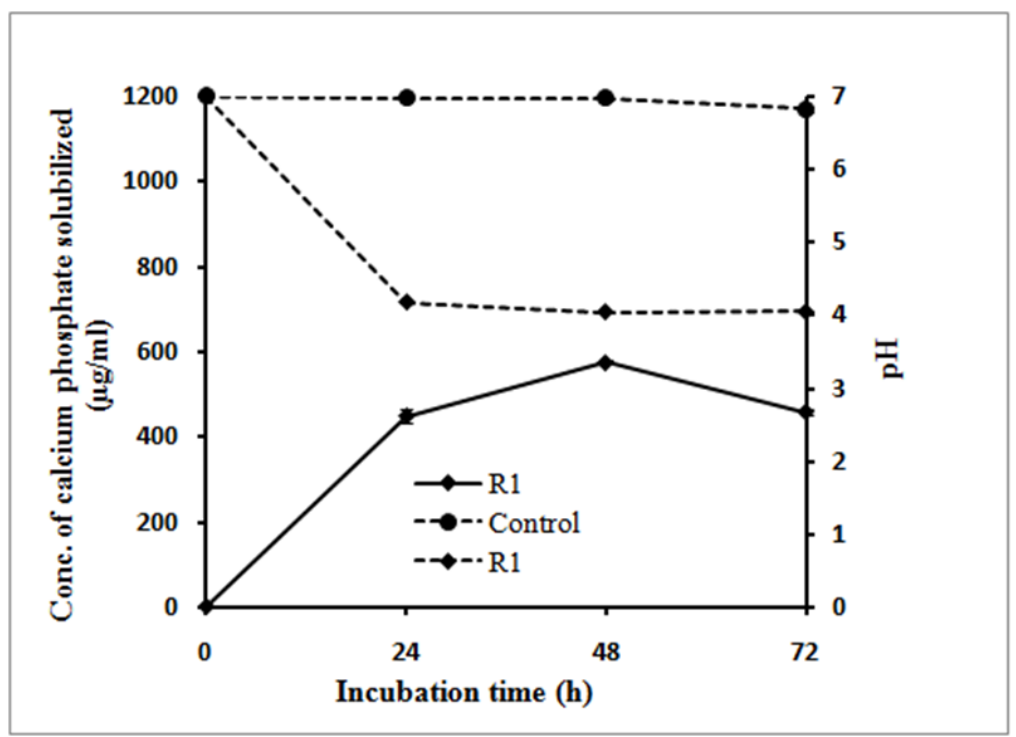

Fig. 1: Time course calcium phosphate solubilization by the PGPB R1 up to $3 \mathrm{~d}$ and corresponding change in $\mathrm{pH}$ of broth medium

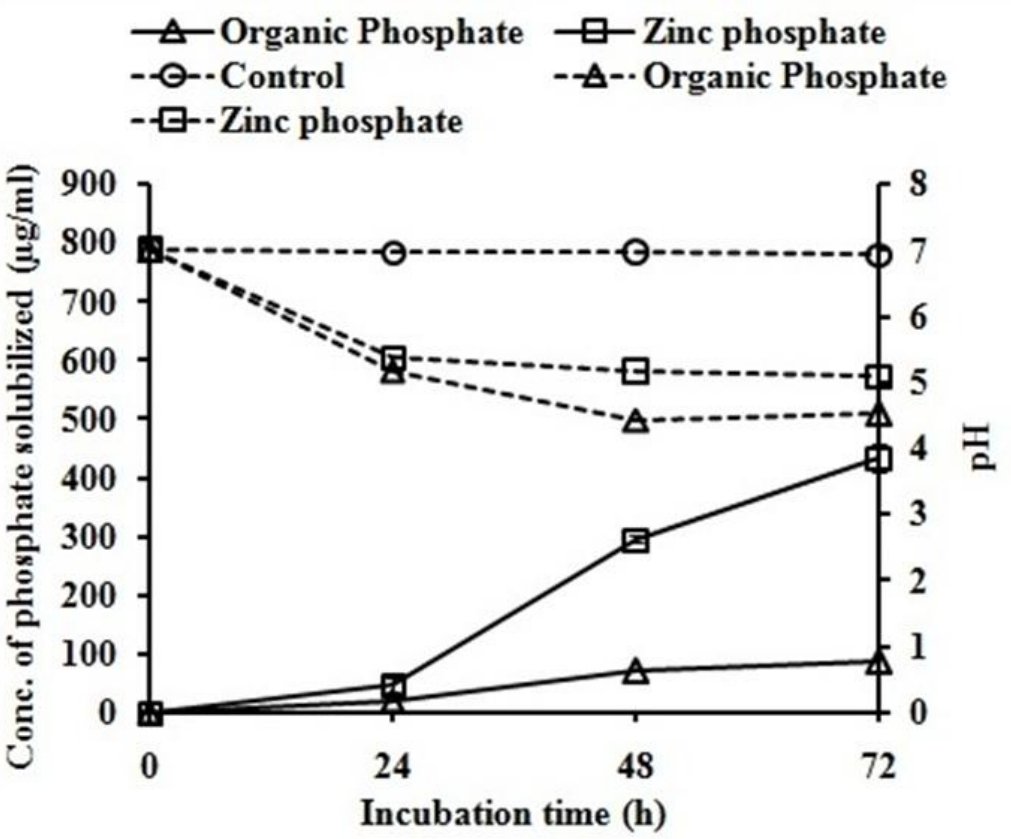

Fig. 2: Solubilization of organic phosphate (phytate) and zinc phosphate in broth culture of the PGPB R1

Solubilization of other forms of phosphates by the rhizoplanic PSB R1

Enterobacter sp. R1 solubilized rock phosphates of Morocco (299.32 $\mu \mathrm{g} / \mathrm{ml}, \mathrm{pH} 4.37)$, North Carolina (486.7 $\mu \mathrm{g} / \mathrm{ml}, \mathrm{pH} 3.57)$, Florida (284.7 $\mu \mathrm{g} / \mathrm{ml}, \mathrm{pH} 3.62)$, Tenesse (159.34 $\mu \mathrm{g} / \mathrm{ml}, \mathrm{pH} 3.75)$ and Gafsa $(495.5 \mu \mathrm{g} / \mathrm{ml}, \mathrm{pH}$ 3.83) and slag (13.614 $\mu \mathrm{g} / \mathrm{ml}, 4.94 \mathrm{pH}$ ) (Fig. 3). Rate of conversion of the phosphates were 41, 14.2, 38.9, 25.9, 12.9 and $29.3 \%$ for Morocco, North Carolina, Florida, Tenesse, Gafsa rock phosphates and slag, respectively (Table 2).

Table 2: Conversion (\%) rate in different phosphates in broth culture of the phosphate solubilizer R1

\begin{tabular}{|c|c|c|c|}
\hline \multirow{2}{*}{ Rock phosphate source } & \multicolumn{3}{|c|}{ Time (h) course conversion (\%) of RP } \\
\cline { 2 - 4 } & $\mathbf{2 4}$ & $\mathbf{4 8}$ & $\mathbf{7 2}$ \\
\hline Morocco & $41.00 \pm 2.90$ & $40.41 \pm 2.87$ & $39.34 \pm 3.30$ \\
\hline North Carolina & $14.22 \pm 0.20$ & $76.05 \pm 0.07$ & $74.73 \pm 0.04$ \\
\hline Florida & $38.92 \pm 0.16$ & $39.27 \pm 0.12$ & $40.10 \pm 0.03$ \\
\hline
\end{tabular}


Nilima Dash, Tushar Kanti Dangar,, 2019. Phosphate mineralization by a rice (Oryza sativa L.) rhizoplanic Enterobacter sp./American-Eurasian Journal of Sustainable Agriculture. 13(4): 1-17.DOI: 10.22587/aejsa.2019.13.4.1

\begin{tabular}{|c|r|r|r|}
\hline Tenesse & $25.92 \pm 0.08$ & $26.55 \pm 0.16$ & $26.08 \pm 0.33$ \\
\hline Gafsa & $12.87 \pm 0.12$ & $81.66 \pm 0.06$ & $82.58 \pm 0.99$ \\
\hline Slag & $29.34 \pm 6.27$ & $34.74 \pm 6.71$ & $35.79 \pm 3.66$ \\
\hline
\end{tabular}

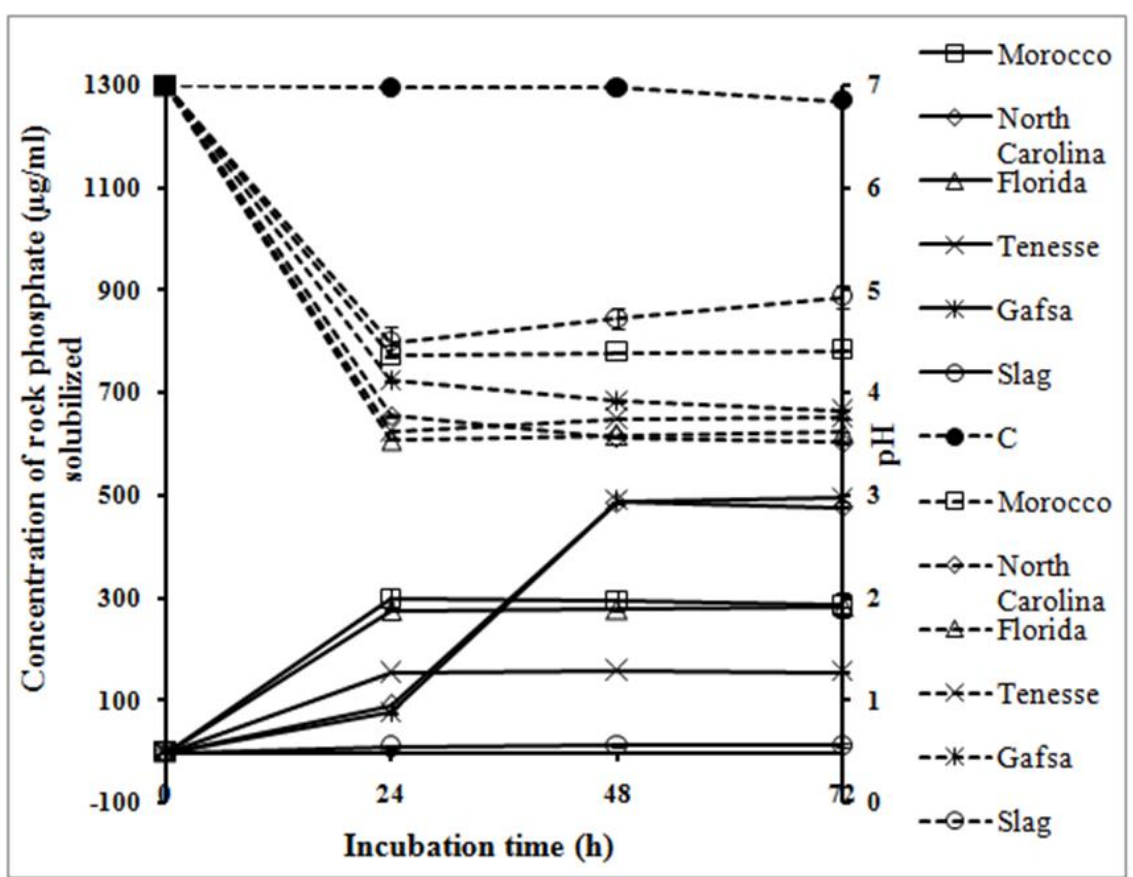

Fig. 3: Kinetics of solubilization of different rock phosphates, slag and $\mathrm{pH}$ change in broth culture of the PGPB R1

Amplification of $p q q$ gene of the rhizoplanic PSB R1

The Enterobacter sp. R1 contained the 546 bp long $p q q \mathrm{C}$ gene (Fig. 4). The $p q q \mathrm{C}$ gene sequence has been submitted to NCBI GenBank (MH221197), which has 75.9 and $73.4 \%$ nucleotide similarities to $p q q \mathrm{C}$ sequences of Pseudomonas syringae (NC_007005.1) and Pseudomonas sp. [17], respectively. The size of the coding protein was 182 amino acids (AWX24480).

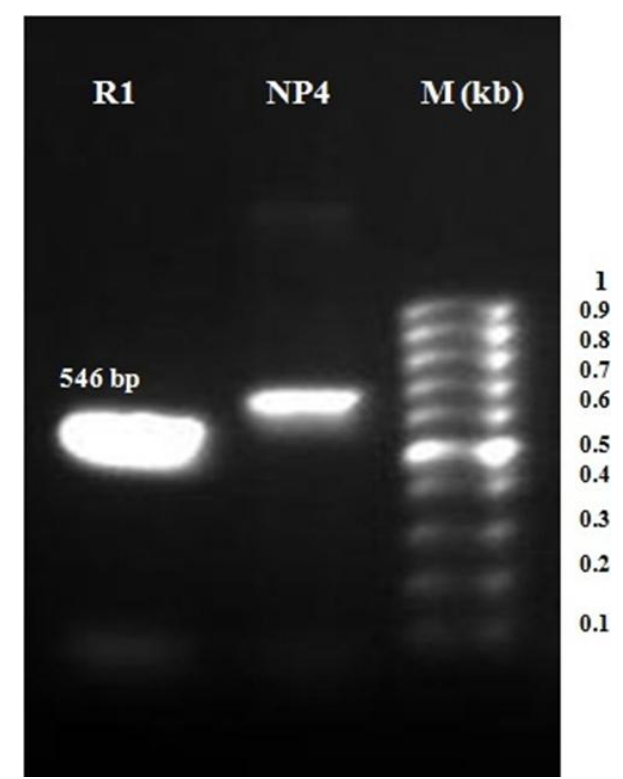

Fig. 4: Profile of amplified $p q q \mathrm{C}$ gene of the PGPB R1 on agarose gel electrophoresis (AGE) plate Footnote- NP4- amplification using another isolate

Production of acid and alkaline phosphatases by the rhizoplanic PSB R1 
Nilima Dash, Tushar Kanti Dangar., 2019. Phosphate mineralization by a rice (Oryza sativa L.) rhizoplanic Enterobacter sp./American-Eurasian Journal of Sustainable Agriculture. 13(4): 1-17.DOI: 10.22587/aejsa.2019.13.4.1

Acid phosphatase $(22.25 \mathrm{U} / \mathrm{ml})$ and alkaline phosphatase $(76.37 \mathrm{U} / \mathrm{ml})$ production by $\mathrm{R} 1$ were highest at $72 \mathrm{~h}$ in NBRIP medium.

\section{Separation and identification of organic acids}

On TLC plates, two OAs i.e. citric acid (Rf 0.62) and lactic acid (Rf 0.89) could be detected (Fig. 5) but 6 OA peaks for R1 culture filtrate were detected by HPLC (Fig. 6). The R1 produced $38.97 \mu \mathrm{M} / \mathrm{ml}$ tartaric acid, 19.22 $\mu \mathrm{M} / \mathrm{ml}$ malic acid, $129.08 \mu \mathrm{M} / \mathrm{ml}$ lactic acid, $68.08 \mu \mathrm{M} / \mathrm{ml}$ acetic acid, $7.34 \mu \mathrm{M} / \mathrm{ml}$ citric acid and $28.29 \mu \mathrm{M} / \mathrm{ml}$ succinic acid (Fig. 6).

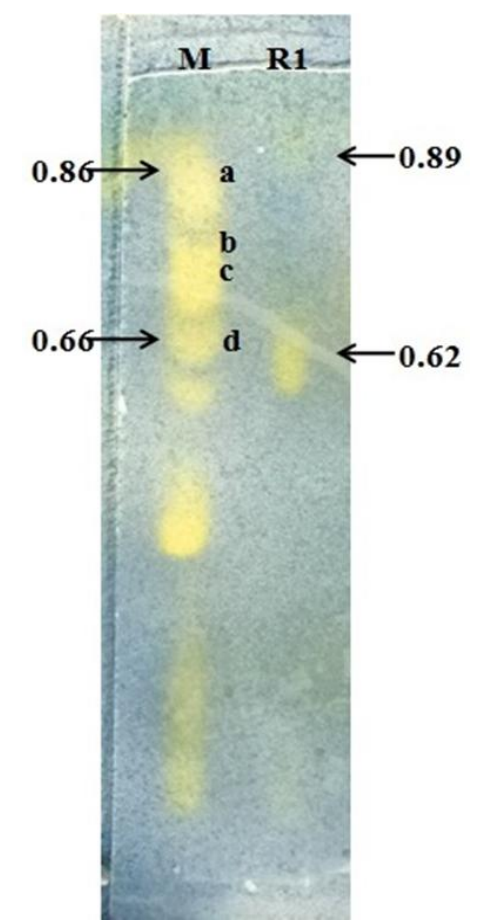

Fig. 5: Identification of different organic acids produced by the PGPB R1 by TLC Footnote- a- Lactic acid, b- Oxalic acid, c- Fumaric acid, d- Citric acid

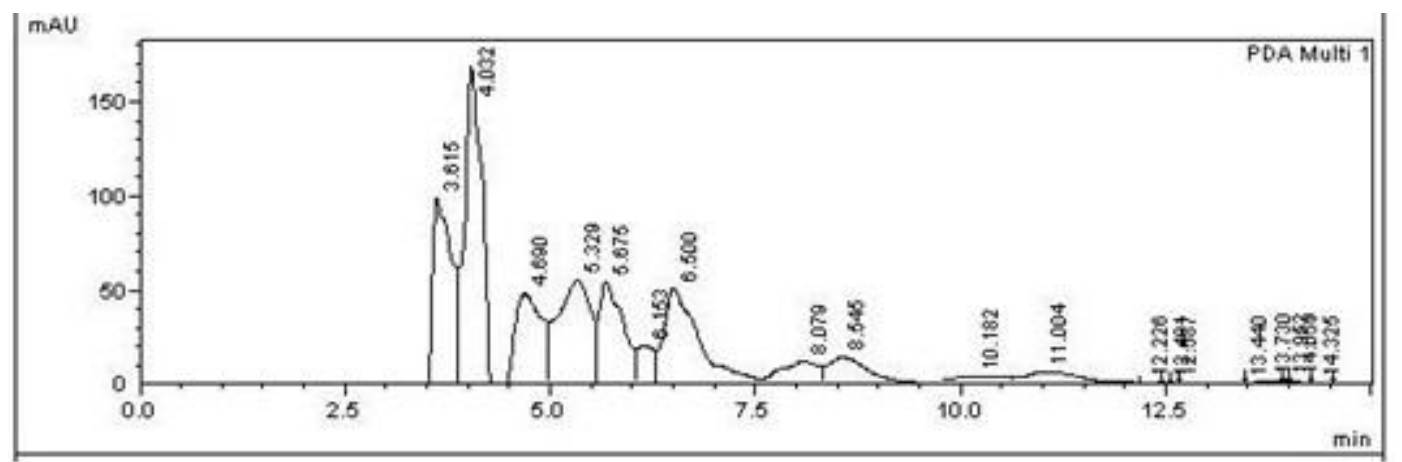

Fig. 6: Identification and quantification of organic acids produced by the PGPB R1 by HPLC

Footnote- 3.615- Tartaric acid, 4.69- Malic acid, 5.329- Lactic acid, 6.5- Acetic acid, 8.079- Citric acid, 8.545Succinic acid

\section{Survivability of the rhizoplanic PSB R1 with preservatives}

The organism remained viable and attained maximum cell count $\left(5.22 \times 10^{7}\right.$ cells $\left./ \mathrm{ml}\right)$ on $100 \mathrm{~d}$ with combinations of $0.1 \%$ citric acid, $0.2 \%$ sodium benzoate and $0.1 \%$ glycerol (Table 3 ). Combinations of $0.1 \%$ citric acid, $0.2 \%$ sodium benzoate, $0.003 \%$ formaldehyde and $0.1 \%$ glycerol could not maintain population (Table 3 ) and only $0.003 \%$ formaldehyde killed the bacteria within 50d (Table 3). 
Nilima Dash, Tushar Kanti Dangar., 2019. Phosphate mineralization by a rice (Oryza sativa L.) rhizoplanic Enterobacter sp./American-Eurasian Journal of Sustainable Agriculture. 13(4): 1-17.DOI: 10.22587/aejsa.2019.13.4.1

Table 3: Effect of preservatives on survival of the phosphate solubilizer R1

\begin{tabular}{|c|c|c|}
\hline $\begin{array}{c}\text { Citric acid, sodium benzoate, } \\
\text { formaldehyde, glycerol }(\boldsymbol{\%})^{*}\end{array}$ & $\begin{array}{c}\text { Population } \\
\text { (cells/ml) after 50d }\end{array}$ & $\begin{array}{c}\text { Population (cells/ml) } \\
\text { after 100d }\end{array}$ \\
\hline $0,0.2,0.003,0.1$ & $1.8 \times 10^{6}$ & $2.25 \times 10^{6}$ \\
\hline $0.01,0.2,0.003,0.1$ & $1.3 \times 10^{6}$ & $2.24 \times 10^{6}$ \\
\hline $0.1,0.2,0.003,0.1$ & $5.3 \times 10^{5}$ & $1.08 \times 10^{6}$ \\
\hline $0.1,0,0.003,0.1$ & $3.2 \times 10^{5}$ & $2.26 \times 10^{6}$ \\
\hline $0.1,0.01,0.003,0.1$ & $3.31 \times 10^{5}$ & $9.1 \times 10^{5}$ \\
\hline $0.1,0.1,0.003,0.1$ & $2.8 \times 10^{6}$ & $3.1 \times 10^{7}$ \\
\hline $0.1,0.2,0.003,0.1$ & $2.1 \times 10^{6}$ & $3.0 \times 10^{7}$ \\
\hline $0.1,0.2,0,0.1$ & $3.2 \times 10^{7}$ & $5.22 \times 10^{7}$ \\
\hline $0.1,0.2,0.003,0.1$ & $1.3 \times 10^{7}$ & $1.35 \times 10^{7}$ \\
\hline $0.1,0.2,0.003,0$ & $2.1 \times 10^{7}$ & $2.08 \times 10^{6}$ \\
\hline $0.1,0.2,0.003,0.01$ & $3.3 \times 10^{7}$ & $6.1 \times 10^{5}$ \\
\hline $0.1,0.2,0.003,0.1$ & $2.42 \times 10^{7}$ & $2.8 \times 10^{6}$ \\
\hline $0,0,0.003,0$ & 0 & 0 \\
\hline $0.1,0,0,0$ & $3.6 \times 10^{6}$ & $4.2 \times 10^{6}$ \\
\hline $0,0.2,0,0$ & $4.1 \times 10^{6}$ & $2.1 \times 10^{7}$ \\
\hline $0,0,0,0.1$ & $3.82 \times 10^{6}$ & $5.8 \times 10^{6}$ \\
\hline
\end{tabular}

*Conc. of the preservatives are given as in the order of heading in the column.

Initial population was $1.2 \times 10^{5} \mathrm{cfu} / \mathrm{ml}$

Effect of the rhizoplanic PSB R1 on growth of rice seedlings in the laboratory

Enterobacter sp. R1 enhanced growth of rice seedlings (Fig. 7) viz. 66.67\% root length, $40 \%$ root number and $28.81 \%$ shoot length over control after $8 \mathrm{~d}$. Fr. and dr. wt. of seedlings also enhanced significantly (Table 4).

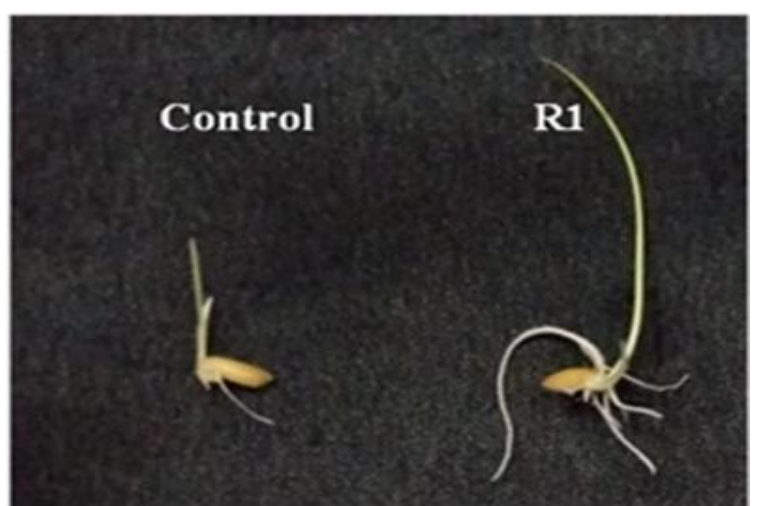

Fig. 7: Effect of the PGPB R1 treatment on rice cv. Naveen seedlings in laboratory

Table 4: Effect of the PGPB R1 on growth of rice cv. Naveen seedlings on moist filter paper in petridish in laboratory

\begin{tabular}{|c|c|c|c|c|c|c|c|c|}
\hline \multirow[b]{2}{*}{ Treatment } & \multicolumn{8}{|c|}{ Parameters } \\
\hline & $\begin{array}{c}\text { Root } \\
\text { length } \\
(\mathrm{cm}) \text { after } \\
\text { 5d }\end{array}$ & $\begin{array}{l}\text { Root no. } \\
\text { after 5d }\end{array}$ & $\begin{array}{c}\text { Shoot } \\
\text { length } \\
(\mathrm{cm}) \text { after } \\
5 \mathrm{~d}\end{array}$ & $\begin{array}{c}\text { Root } \\
\text { length } \\
(\mathrm{cm}) \text { after } \\
\text { 8d }\end{array}$ & $\begin{array}{c}\text { Root } \\
\text { no. } \\
\text { after 8d }\end{array}$ & $\begin{array}{c}\text { Shoot } \\
\text { length } \\
(\mathrm{cm}) \\
\text { after 8d }\end{array}$ & $\begin{array}{l}\text { Fr. wt. } \\
\text { (g) after } \\
\text { 8d }\end{array}$ & $\begin{array}{l}\text { Dr. wt. } \\
\text { (g) after } \\
\text { 8d }\end{array}$ \\
\hline Control & 1.3 & 1 & 2 & 1.8 & 5 & 5.9 & 0.015 & 0.002 \\
\hline R1 & 2.7 & 7 & 5.4 & 3 & 10 & 7.6 & 0.046 & 0.006 \\
\hline $\operatorname{LSD}(5 \%)$ & 0.24 & 3.74 & 1.39 & 0.98 & 2.45 & 2.87 & 0.02 & 0.02 \\
\hline $\mathrm{CV}(5 \%)$ & 3.5 & 25.9 & 10.9 & 11.6 & 9.9 & 12.3 & 8.3 & 10.2 \\
\hline p-value & $\begin{array}{c}0.0010 * * \\
*\end{array}$ & $0.0199 *$ & $0.0064 * *$ & $0.0319 *$ & $\begin{array}{c}0.0100 \\
* *\end{array}$ & 0.1375 & $\begin{array}{c}0.0029 \\
* *\end{array}$ & $\begin{array}{c}0.0120 \\
*\end{array}$ \\
\hline
\end{tabular}

Values are means of three replications and data calculated per seedling basis. LSD- least significant difference; $\mathrm{CV}$ - coefficient of variance. Level of significance $* \mathrm{p}<0.05, * * \mathrm{p}<0.01, * * * \mathrm{p}<0.001$

Effects of the rhizoplanic PSB R1 and isolate from commercial biofertilizer on growth of rice seedlings 
Nilima Dash, Tushar Kanti Dangar., 2019. Phosphate mineralization by a rice (Oryza sativa L.) rhizoplanic Enterobacter sp./American-Eurasian Journal of Sustainable Agriculture. 13(4): 1-17.DOI: 10.22587/aejsa.2019.13.4.1

Root length of plants increased (but insignificant) by $67.11 \%$, and $51.32 \%$ in $\mathrm{T} 2$ and $\mathrm{T} 3$, respectively over control (T1) and about $10.43 \%$ more in treatment T2 than commercial bacteria (T3). Increase of fr. and dr. wt. of roots was significant at $\mathrm{p}<0.05$ and was optimum in treatment T2 (Fig. 8). Shoot length also increased significantly at $\mathrm{p}<0.05$ (Table 5).

Table 5: Effect of the PGPB R1 and a commercial PS isolate on rice cv. Naveen seedling growth promotion cultured on soil in the laboratory

\begin{tabular}{|c|c|c|c|c|c|c|}
\hline Growth parameters & T1 & T2 & T3 & LSD (5\%) & CV (\%) & p-value \\
\hline Root length $(\mathrm{cm})$ & 7.6 & 12.7 & 11.5 & 13.61 & 56.6 & 0.6015 \\
\hline Shoot length (cm) & 23.2 & 30.3 & 30.5 & 5.20 & 8.2 & $0.0296^{*}$ \\
\hline Fr. wt. of root $(\mathrm{g})$ & 0.06 & 0.15 & 0.14 & 0.01 & 20.1 & $0.0209^{*}$ \\
\hline Dr. wt. of root $(\mathrm{g})$ & 0.01 & 0.05 & 0.04 & 0.01 & 38.7 & $0.0468^{*}$ \\
\hline Fr. wt. of shoot $(\mathrm{g})$ & 0.17 & 0.28 & 0.31 & 0.11 & 20.1 & 0.0598 \\
\hline Dr. wt. of shoot (g) & 0.02 & 0.06 & 0.07 & 0.01 & 40.7 & 0.0875 \\
\hline
\end{tabular}

T1- Control, T2- Enterobacter sp. R1, T3- Commercial biofertilizer.

Values are means of three replications and data calculated per plant. LSD- least significant difference; CVcoefficient of variance. Level of significance $* p<0.05$

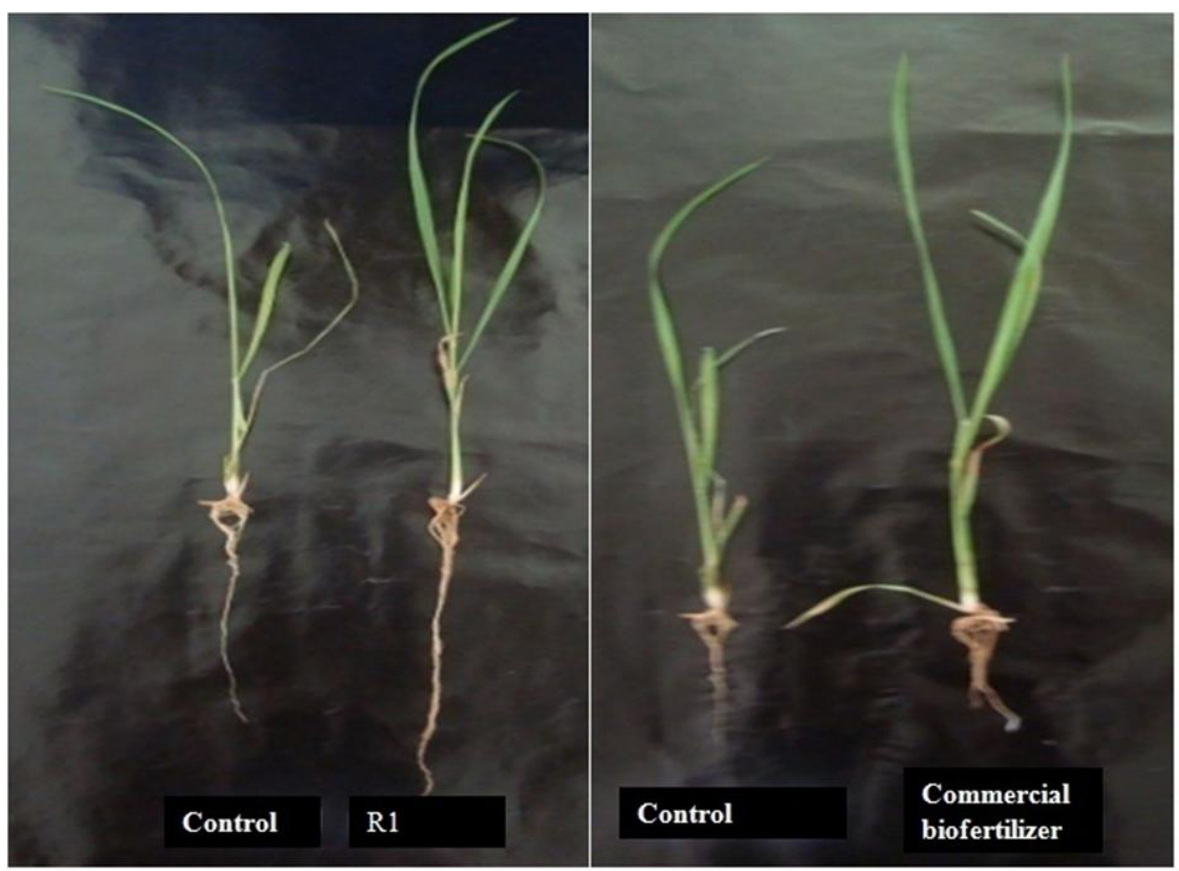

Fig. 8: Effect of the PGPB R1 and a commercial biofertilizer treatment on growth of rice cv. Naveen seedlings

Effect of the rhizoplanic PSB R1 on growth of rice seedling in pot culture

Enterobacter sp. alone increased plant height by 2.65\% (Table 6) and treatment with R1, recommended dose of $\mathrm{N}$ and $\mathrm{K}$ and half $\mathrm{P}$ (T5) enhanced $10.39 \%$ height over control (Table 6, Fig. 9). Increase of root length was $6.82 \%$ and $33.52 \%$ for $\mathrm{T} 4$ and $\mathrm{T} 5$, respectively and root fr. wt. about $15.6 \%$ and $33.68 \%$ for $\mathrm{T} 4$ and $\mathrm{T} 5$, respectively over control and root dr. wt. enhancement was significant for T4 (14.9\%) and T5 $(41.36 \%)$ over untreated plants. The fr. wt. (9.98\% in T4 and 33.91\% in T5) and dr. wt. (14.7\% in T4 and $37.16 \%$ in T5) of shoot were also augmented over untreated plants (Fig. 9). Growth promotion was more for R1 treatment than those received RDF (Table 6).

Table 6: Effect of the PGPB R1 inoculation on growth of rice cv. Naveen seedlings in pot culture in net house

\begin{tabular}{|c|c|c|c|c|c|c|c|c|}
\hline \multirow{2}{*}{$\begin{array}{c}\text { Growth } \\
\text { parameters }\end{array}$} & $\mathbf{T 1}$ & $\mathbf{T 2}$ & $\mathbf{T 3}$ & $\mathbf{T 4}$ & $\mathbf{T 5}$ & $\begin{array}{c}\text { LSD } \\
\mathbf{( 5 \% )}\end{array}$ & $\begin{array}{c}\text { CV } \\
(\mathbf{\%})\end{array}$ & p-value \\
\hline $\begin{array}{c}\text { Plant height } \\
(\mathrm{cm})\end{array}$ & 49.1 & 53.4 & 54.2 & 50.4 & 54.2 & 1.66 & 1.7 & $0.0004 * * *$ \\
\hline $\begin{array}{c}\text { Root length } \\
\text { (cm) }\end{array}$ & 17.6 & 23.3 & 23.6 & 18.8 & 23.5 & 1.94 & 4.8 & $0.0002^{* * *}$ \\
\hline No. of tillers & 5 & 6 & 6 & 4 & 7 & 1.14 & 11.1 & $0.0085^{* *}$ \\
\hline
\end{tabular}


Nilima Dash, Tushar Kanti Dangar,, 2019. Phosphate mineralization by a rice (Oryza sativa L.) rhizoplanic Enterobacter sp./American-Eurasian Journal of Sustainable Agriculture. 13(4): 1-17.DOI: 10.22587/aejsa.2019.13.4.1

\begin{tabular}{|c|c|c|c|c|c|c|c|c|}
\hline Root fr. wt. (g) & 20.96 & 27.81 & 27.86 & 24.23 & 28.02 & 1.34 & 2.8 & $0.0000^{* * *}$ \\
\hline $\begin{array}{c}\text { Root dr. wt. } \\
\text { (g) }\end{array}$ & 7.18 & 9.88 & 10.12 & 8.25 & 10.15 & 1.24 & 7.2 & $0.0019^{* *}$ \\
\hline $\begin{array}{c}\text { Shoot fr. wt. } \\
\text { (g) }\end{array}$ & 39.28 & 52.1 & 52.6 & 43.2 & 52.6 & 2.53 & 2.8 & $0.0000^{* * *}$ \\
\hline $\begin{array}{c}\text { Shoot dr. wt. } \\
\text { (g) }\end{array}$ & 10.2 & 12.81 & 14.08 & 11.7 & 13.99 & 1.65 & 7.0 & $0.0032^{* *}$ \\
\hline No. of leaves & 10 & 11 & 13 & 12 & 13 & 1.03 & 4.6 & $0.0014^{* *}$ \\
\hline $\begin{array}{c}\text { Leaf area } \\
\text { (cm } \text { (m) }^{2}\end{array}$ & 51.51 & 55.42 & 55.42 & 53 & 56.14 & 1.89 & 1.9 & $0.0025^{* *}$ \\
\hline $\begin{array}{c}\text { Panicle length } \\
\text { (cm) }\end{array}$ & 13.2 & 15.7 & 17.6 & 14.4 & 18 & 1.78 & 6.0 & $0.0013^{* *}$ \\
\hline $\begin{array}{c}\text { Panicle weight } \\
\text { (g) }\end{array}$ & 1.2 & 1.31 & 1.33 & 1.24 & 1.33 & 0.01 & 3.4 & $0.0231^{*}$ \\
\hline Grain wt./plant & 2.78 & 3.7 & 4.08 & 3.14 & 4.11 & 0.47 & 7.0 & $0.0008^{* * *}$ \\
\hline $\begin{array}{c}100 \text { grain wt. } \\
\text { (g) }\end{array}$ & 1.94 & 1.95 & 1.96 & 1.94 & 1.97 & 0.02 & 0.4 & $0.0123^{*}$ \\
\hline
\end{tabular}

T1- Control without fertilizer, T2- Recommended dose 120:60:60=N:P:K kg/ha fertilizer (RDF), T3- N: 1/2P: K according to RDF, T4- Only bacteria (R1), T5- Bacteria (R1) + N: 1/2P: K according to RDF

Values are means of three replications and data calculated per plant. LSD- least significant difference; CVcoefficient of variance. Level of significance $* \mathrm{p}<0.05, * * \mathrm{p}<0.01, * * * \mathrm{p}<0.001$

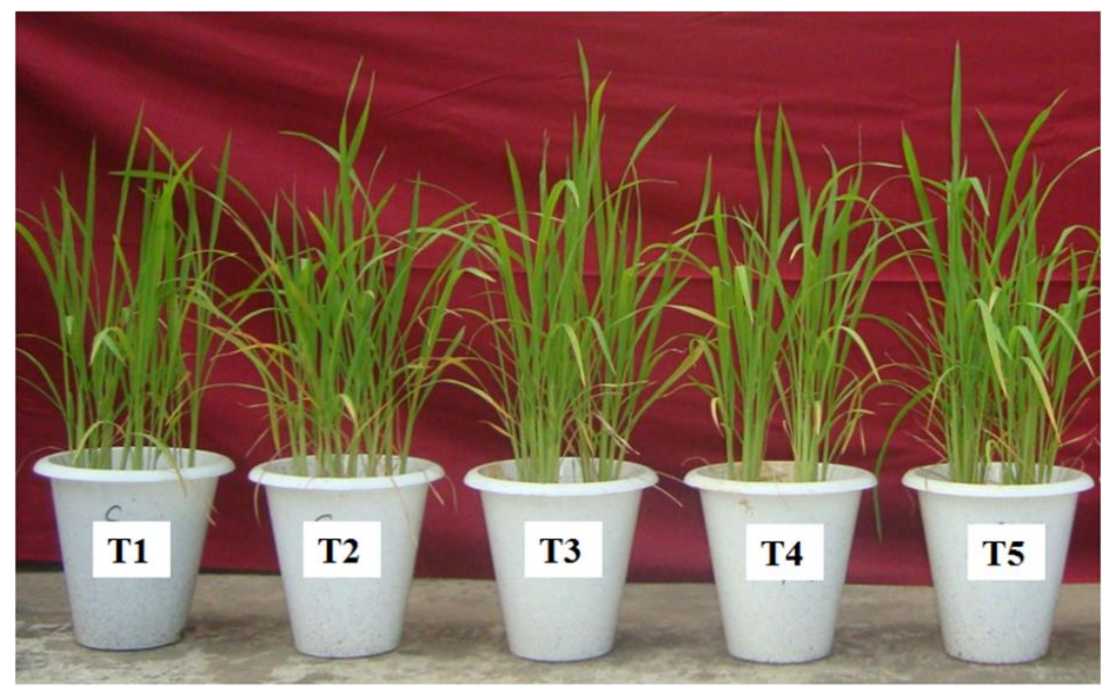

Fig. 9: Effect of the PGPB R1 treatment on growth of rice cv. Naveen seedlings in pot culture in net house

\section{Effect of the rhizoplanic PSB R1on growth of rice in the field}

During rabi season (Table 7), plant height increased by $22.46 \%$ and $12.03 \%$ after $30 \mathrm{~d}$ for $\mathrm{T} 4$ and $\mathrm{T} 5$, respectively and treatment with R1 (T5) only increased $6.05 \%$ height at harvest and T4 effected $12 \%$ height increment, and roots were longer by $39.95 \%$ and $23.27 \%$ for T4 and T5, respectively, compared to control (T1). Increment of fr. (12.09\%) and dr. wt. (25.09\%) of root over control was significant for R1 (T5) treatment only and $31.35 \%$ and $33.83 \%$ increase of fr. and dr. wt. of roots was observed for R1, N and K fertilizers and half dose of P fertilizer (T4) treatment (Fig. 10). Shoot fr. wt. was also more $(21.97 \%)$ in T5 and dr. wt. was increased for T4 and T5 by $43.9 \%$ and $13.7 \%$, respectively, over control (Table 7).

During kharif season, stagnation of flood water affected timely fertilizer application resulting in overall stunted growth of the crop. After $30 \mathrm{~d}, 25.23 \%$ and $7.34 \%$ increase and at harvest, $9.63 \%$ and $7.38 \%$ increase in height of T4 and T5 plants was observed (Table 8). Root lengths also increased by $26.47 \%$ and $16.18 \%$ for T4 and T5, respectively (Table 8$)$. Increase in fr. wt. (4.66\%) and dr. wt. (10.8\%) of roots for bacterial treatment only (T5). $\mathrm{R} 1, \mathrm{~N}$ and $\mathrm{K}$ and half P fertilizer treatment (T4) increased fr. and dr. wt. of roots by $32.06 \%$ and $29.82 \%$, fr. and dr. wt. of shoots by $27.65 \%$ and $35.9 \%$ and grain yield by $17.65 \%$, respectively, over control (Table 8 ) (Fig. 11). R1 alone (T5) increased $13.53 \%$ and $19.58 \%$ fr. and dr. wt. of shoots. Bacterium only treatment (T5) enhanced $7.35 \%$ grain yield (Fig. 11). 
Nilima Dash, Tushar Kanti Dangar,, 2019. Phosphate mineralization by a rice (Oryza sativa L.) rhizoplanic Enterobacter sp./American-Eurasian Journal of Sustainable Agriculture. 13(4): 1-17.DOI: 10.22587/aejsa.2019.13.4.1

Table 7: Effect of the PGPB R1 inoculation on growth of rice cv. Naveen seedlings in field during rabi season

\begin{tabular}{|c|c|c|c|c|c|c|c|c|c|}
\hline \multirow[b]{2}{*}{$\begin{array}{c}\text { Paramete } \\
\text { rs }\end{array}$} & \multicolumn{6}{|c|}{ Treatment } & \multirow{2}{*}{$\begin{array}{c}\text { LS } \\
\text { D } \\
(\mathbf{5 \%} \\
\quad) \\
\end{array}$} & \multirow[b]{2}{*}{$\begin{array}{c}\text { CV } \\
(\% \\
)\end{array}$} & \multirow[b]{2}{*}{ p-value } \\
\hline & T1 & $\mathbf{T} 2$ & T3 & T4 & T5 & T6 & & & \\
\hline $\begin{array}{l}\text { Plant } \\
\text { height } \\
(\mathrm{cm})\end{array}$ & 37.4 & 42.7 & 44.3 & 45.8 & 41.9 & 42.2 & 4.09 & 5.3 & $0.0180 *$ \\
\hline $\begin{array}{c}\text { No. of } \\
\text { tillers } \\
\text { after 30d }\end{array}$ & 4 & 5 & 5 & 5 & 5 & 5 & 1.03 & $\begin{array}{c}11 . \\
6\end{array}$ & $0.0299 *$ \\
\hline $\begin{array}{c}\text { Plant } \\
\text { height at } \\
\text { harvest } \\
(\mathrm{cm})\end{array}$ & $\begin{array}{c}105 . \\
8\end{array}$ & 115 & 116.8 & 118.5 & $\begin{array}{c}112 . \\
2\end{array}$ & 113.8 & 5.89 & 2.9 & $0.0101 *$ \\
\hline $\begin{array}{c}\text { No. of } \\
\text { tillers } \\
\text { after } 90 \mathrm{~d}\end{array}$ & 8 & 10 & 11 & 11 & 9 & 10 & 1.03 & 5.9 & $\begin{array}{c}0.0007 * \\
* *\end{array}$ \\
\hline $\begin{array}{c}\text { Root } \\
\text { length } \\
(\mathrm{cm})\end{array}$ & 20.2 & 27 & 27.4 & 28.27 & 24.9 & 26.1 & 4.73 & $\begin{array}{c}10 . \\
1\end{array}$ & $0.0358 *$ \\
\hline $\begin{array}{l}\text { Root fr. } \\
\text { wt. (g) }\end{array}$ & $\begin{array}{c}25.2 \\
3\end{array}$ & 32.12 & 33 & 33.14 & $\begin{array}{c}28.2 \\
8\end{array}$ & 30.91 & 2.35 & 4.2 & $\begin{array}{c}0.0002 * \\
* *\end{array}$ \\
\hline $\begin{array}{l}\text { Root dr. } \\
\text { wt. (g) }\end{array}$ & 5.38 & 7.09 & 7.18 & 7.2 & 6.73 & 7.07 & 0.62 & 5.1 & $\begin{array}{c}0.0006^{*} \\
* *\end{array}$ \\
\hline $\begin{array}{l}\text { Shoot fr. } \\
\text { wt. (g) }\end{array}$ & $\begin{array}{c}75.6 \\
9\end{array}$ & $\begin{array}{c}123.6 \\
1\end{array}$ & $\begin{array}{c}141.8 \\
3\end{array}$ & $\begin{array}{c}142.0 \\
1\end{array}$ & $\begin{array}{c}92.3 \\
2\end{array}$ & $\begin{array}{c}117.9 \\
1\end{array}$ & $\begin{array}{c}29.7 \\
7\end{array}$ & $\begin{array}{c}14 . \\
2\end{array}$ & $\begin{array}{c}0.0030 * \\
*\end{array}$ \\
\hline $\begin{array}{c}\text { Shoot dr. } \\
\text { wt. (g) }\end{array}$ & $\begin{array}{c}22.8 \\
5\end{array}$ & 27.92 & 31.82 & 32.9 & $\begin{array}{c}25.9 \\
8 \\
\end{array}$ & 27.1 & 9.04 & $\begin{array}{c}17 . \\
7 \\
\end{array}$ & 0.2210 \\
\hline $\begin{array}{l}\text { Panicle } \\
\text { length } \\
(\mathrm{cm})\end{array}$ & 19.8 & 24.1 & 24.9 & 25.9 & 21.5 & 23.3 & 2.79 & 6.6 & $\begin{array}{c}0.0062 * \\
*\end{array}$ \\
\hline $\begin{array}{c}\text { Panicle } \\
\text { weight }(\mathrm{g})\end{array}$ & 9.99 & 14.97 & 15.28 & 15.73 & $\begin{array}{c}10.4 \\
5\end{array}$ & 12.63 & 2.02 & 8.4 & $\begin{array}{c}0.0003 * \\
* *\end{array}$ \\
\hline $\begin{array}{c}\text { Grain } \\
\text { yield/plant }\end{array}$ & 139 & 157 & 160 & 171 & 144 & 151 & 7.42 & 2.7 & $\begin{array}{c}0.0000^{*} \\
* *\end{array}$ \\
\hline chaps & 10 & 8 & 7 & 6 & 7 & 7 & 1.63 & $\begin{array}{c}12 . \\
5\end{array}$ & $\begin{array}{c}0.0037 * \\
*\end{array}$ \\
\hline $\begin{array}{l}1000 \mathrm{gr} \\
\text { wt. }(\mathrm{g})\end{array}$ & $\begin{array}{c}18.9 \\
3 \\
\end{array}$ & 20.07 & 20.66 & 20.91 & 19.8 & 19.94 & 0.86 & 2.3 & $\begin{array}{c}0.0061 * \\
*\end{array}$ \\
\hline Chl a & 1.53 & 2.47 & 2.56 & 2.74 & 2 & 2.43 & 0.01 & 1.0 & $\begin{array}{c}0.0000^{*} \\
* *\end{array}$ \\
\hline Chl b & 0.48 & 1.07 & 1.16 & 1.34 & 0.61 & 1.09 & 0.01 & 5.5 & $\begin{array}{c}0.0000^{*} \\
* *\end{array}$ \\
\hline $\begin{array}{c}\mathrm{Chl} \mathrm{a} \mathrm{+} \\
\mathrm{Chl} \mathrm{b}\end{array}$ & 2.01 & 3.54 & 3.72 & 4.08 & 2.61 & 3.52 & 0.12 & 2.0 & $\begin{array}{c}0.0000 * \\
* *\end{array}$ \\
\hline
\end{tabular}

T1- Control without any fertilizer, T2- RDF of N: P: K, T3- N: 1/2 P: K according to RDF, T4- Bacteria + N: 1/2P: $\mathrm{K}$ according to RDF, T5- Only bacteria, T6- N+K (according to RDF)

Values are means of three replications and data calculated per plant. LSD- least significant difference; CVcoefficient of variance. Level of significance $* \mathrm{p}<0.05, * * \mathrm{p}<0.01, * * * \mathrm{p}<0.001$ 
Nilima Dash, Tushar Kanti Dangar,, 2019. Phosphate mineralization by a rice (Oryza sativa L.) rhizoplanic Enterobacter sp./American-Eurasian Journal of Sustainable Agriculture. 13(4): 1-17.DOI: 10.22587/aejsa.2019.13.4.1

Table 8: Effect of the PGPB R1 inoculation on growth of rice cv. Naveen seedlings in field during kharif season

\begin{tabular}{|c|c|c|c|c|c|c|c|c|c|}
\hline \multirow{2}{*}{$\begin{array}{c}\text { Parameter } \\
\text { s }\end{array}$} & \multicolumn{6}{|c|}{ Treatment } & \multirow{2}{*}{$\begin{array}{c}\text { LSD } \\
(5 \% \\
\quad) \\
\end{array}$} & \multirow{2}{*}{$\begin{array}{c}\mathrm{CV} \\
(\% \\
)\end{array}$} & \multirow{2}{*}{ p-value } \\
\hline & T1 & $\mathbf{T 2}$ & T3 & T4 & T5 & T6 & & & \\
\hline $\begin{array}{l}\text { Plant } \\
\text { height } \\
(\mathrm{cm})\end{array}$ & 21.8 & 26.4 & 26.1 & 27.3 & 23.4 & 24.2 & 3.62 & 8.0 & 0.0506 \\
\hline $\begin{array}{c}\text { No. of } \\
\text { tillers after } \\
\text { 30d }\end{array}$ & 6 & 11 & 13 & 14 & 9 & 10 & 2.29 & $\begin{array}{c}11 . \\
9\end{array}$ & $\begin{array}{c}0.0005^{* *} \\
*\end{array}$ \\
\hline $\begin{array}{c}\text { Plant } \\
\text { height at } \\
\text { harvest } \\
(\mathrm{cm})\end{array}$ & 62.3 & 68.2 & 68.1 & 68.3 & 66.9 & 67.6 & 4.89 & 4.0 & 0.1317 \\
\hline $\begin{array}{c}\text { No. of } \\
\text { tillers after } \\
90 \mathrm{~d} \\
\end{array}$ & 14 & 25 & 25 & 25 & 20 & 21 & 3.97 & $\begin{array}{c}10 . \\
1\end{array}$ & $\begin{array}{c}0.0007 * * \\
*\end{array}$ \\
\hline $\begin{array}{c}\text { Root } \\
\text { length } \\
(\mathrm{cm})\end{array}$ & 13.6 & 16.7 & 17.1 & 17.2 & 15.8 & 16.2 & 1.92 & 6.6 & $0.0182 *$ \\
\hline $\begin{array}{l}\text { Root fr. wt. } \\
(\mathrm{g})\end{array}$ & $\begin{array}{c}15.4 \\
4 \\
\end{array}$ & $\begin{array}{c}19.8 \\
2 \\
\end{array}$ & $\begin{array}{c}20.2 \\
3 \\
\end{array}$ & $\begin{array}{c}20.3 \\
9 \\
\end{array}$ & $\begin{array}{c}16.1 \\
6 \\
\end{array}$ & $\begin{array}{c}18.9 \\
4 \\
\end{array}$ & 2.59 & 7.7 & $0.0051 * *$ \\
\hline $\begin{array}{c}\text { Root dr. } \\
\text { wt. (g) }\end{array}$ & 3.89 & 4.69 & 4.93 & 5.05 & 4.31 & 4.55 & 1.05 & $\begin{array}{c}12 . \\
6 \\
\end{array}$ & 0.2397 \\
\hline $\begin{array}{c}\text { Shoot fr. } \\
\text { wt. (g) }\end{array}$ & $\begin{array}{c}41.7 \\
7 \\
\end{array}$ & $\begin{array}{c}52.5 \\
7 \\
\end{array}$ & $\begin{array}{c}53.2 \\
7 \\
\end{array}$ & $\begin{array}{c}53.3 \\
2 \\
\end{array}$ & $\begin{array}{c}47.4 \\
2 \\
\end{array}$ & $\begin{array}{c}50.2 \\
7 \\
\end{array}$ & 3.33 & 3.7 & $\begin{array}{c}0.0001 * * \\
*\end{array}$ \\
\hline $\begin{array}{c}\text { Shoot dr. } \\
\text { wt. (g) }\end{array}$ & 9.04 & $\begin{array}{c}12.0 \\
4 \\
\end{array}$ & $\begin{array}{c}12.2 \\
4 \\
\end{array}$ & $\begin{array}{c}12.2 \\
9 \\
\end{array}$ & $\begin{array}{c}10.8 \\
1 \\
\end{array}$ & $\begin{array}{c}11.5 \\
9 \\
\end{array}$ & 1.29 & 6.3 & $0.0019 * *$ \\
\hline $\begin{array}{c}\text { Panicle } \\
\text { length } \\
(\mathrm{cm})\end{array}$ & 17 & 21.3 & 21.1 & 21.8 & 19.6 & 20.3 & 2.05 & 5.6 & $0.0045 * *$ \\
\hline $\begin{array}{c}\text { Panicle } \\
\text { weight }(\mathrm{g})\end{array}$ & 6.29 & 9.26 & $\begin{array}{c}10.0 \\
7\end{array}$ & $\begin{array}{c}10.2 \\
8 \\
\end{array}$ & 8.66 & 8.85 & 1.28 & 7.9 & $\begin{array}{c}0.0006^{* *} \\
*\end{array}$ \\
\hline $\begin{array}{c}\text { Grain } \\
\text { yield/plant }\end{array}$ & 136 & 152 & 157 & 160 & 146 & 148 & 7.49 & 2.7 & $\begin{array}{c}0.0005^{* *} \\
* \\
\end{array}$ \\
\hline chaps & 10 & 8 & 8 & 7 & 9 & 8 & 1.29 & 8.3 & $0.0081 * *$ \\
\hline $\begin{array}{c}1000 \text { gr wt. } \\
(\mathrm{g})\end{array}$ & $\begin{array}{c}17.6 \\
1 \\
\end{array}$ & $\begin{array}{c}18.0 \\
7 \\
\end{array}$ & $\begin{array}{c}18.0 \\
7\end{array}$ & $\begin{array}{c}18.1 \\
7 \\
\end{array}$ & $\begin{array}{c}17.9 \\
1 \\
\end{array}$ & $\begin{array}{c}18.0 \\
2 \\
\end{array}$ & 1.21 & 3.7 & 0.9187 \\
\hline Chl a & 1.46 & 2.45 & 2.54 & 2.66 & 1.94 & 2.41 & 0.01 & 1.5 & $\begin{array}{c}0.0000 * * \\
*\end{array}$ \\
\hline Chl b & 0.43 & 1.01 & 1.18 & 1.28 & 0.53 & 0.95 & 0.11 & 6.6 & $\begin{array}{c}0.0000 * * \\
*\end{array}$ \\
\hline $\begin{array}{c}\text { Chl a + } \\
\text { Chl b }\end{array}$ & 1.89 & 3.46 & 3.72 & 3.94 & 2.47 & 3.36 & 0.10 & 1.8 & $\begin{array}{c}0.0000 * * \\
*\end{array}$ \\
\hline
\end{tabular}

T1- Control without any fertilizer, T2- RDF of N: P: K, T3- N: 1/2 P: K according to RDF, T4- Bacteria + N: 1/2P: $\mathrm{K}$ according to RDF, T5- Only bacteria, T6- N+K (according to RDF)

Values are means of three replications and data calculated per plant. LSD- least significant difference; CVcoefficient of variance. Level of significance $* \mathrm{p}<0.05, * * \mathrm{p}<0.01, * * * \mathrm{p}<0.001$ 
Nilima Dash, Tushar Kanti Dangar., 2019. Phosphate mineralization by a rice (Oryza sativa L.) rhizoplanic Enterobacter sp./American-Eurasian Journal of Sustainable Agriculture. 13(4): 1-17.DOI: 10.22587/aejsa.2019.13.4.1

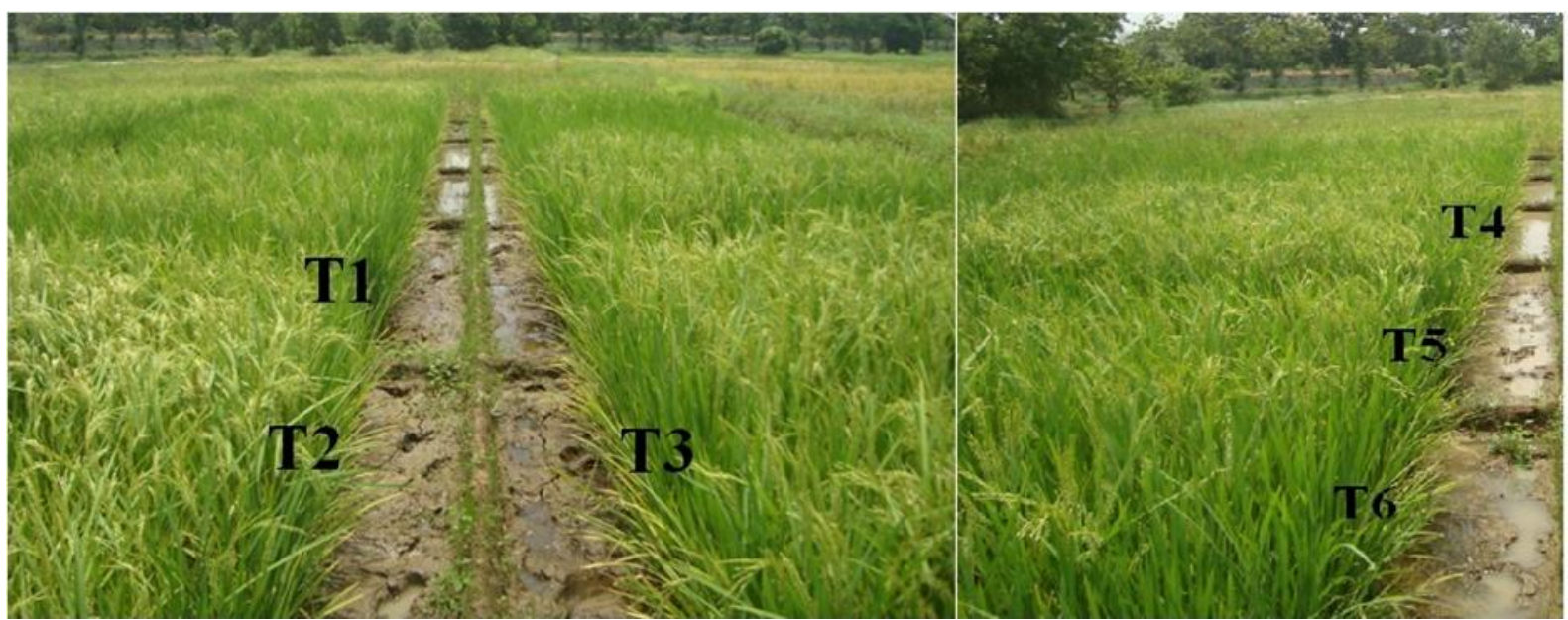

Fig. 10: Effect of the PGPB R1 treatment on growth of rice cv. Naveen in field in rabi season
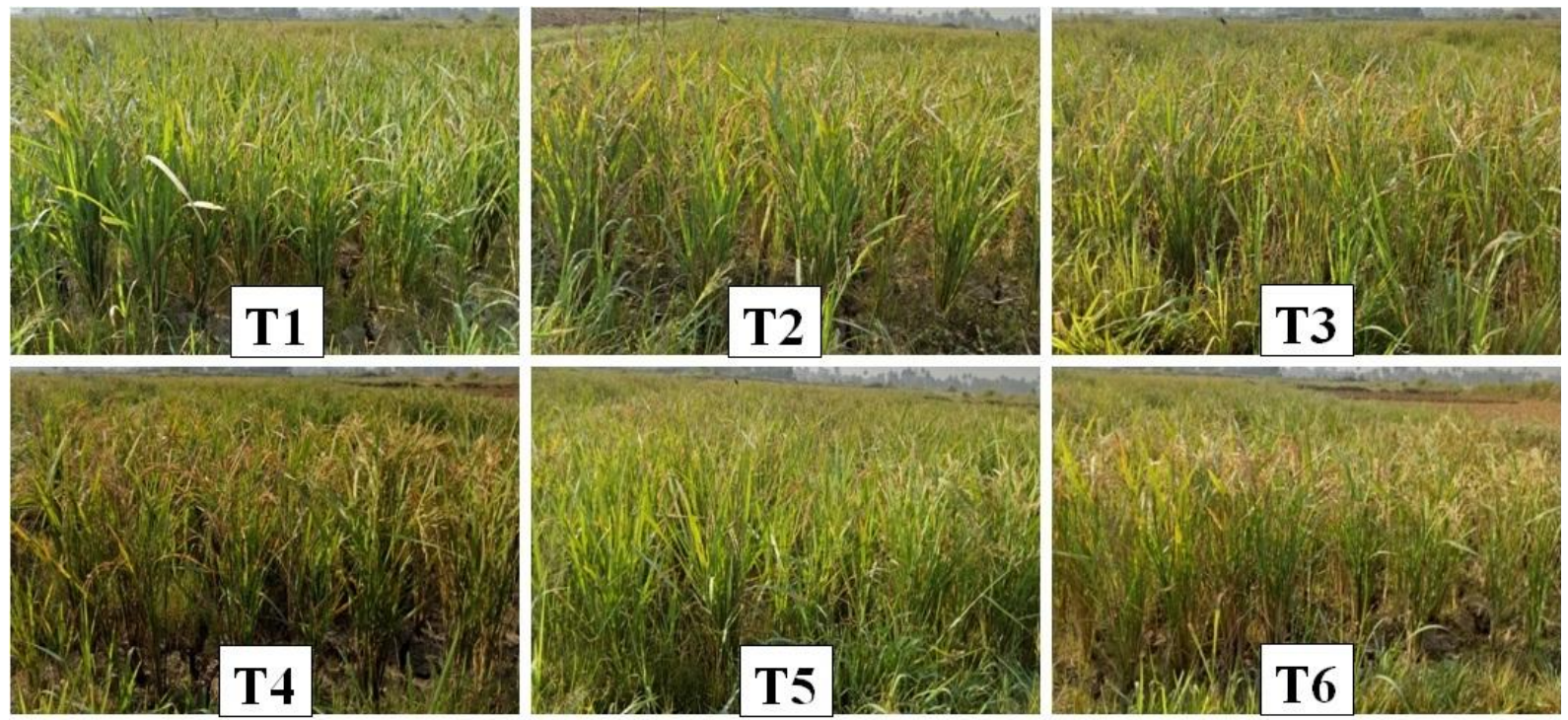

Fig. 11: Effect of the PGPB R1 treatment on growth of rice cv. Naveen in field in kharif season

\section{DISCUSSION}

The Swarna Sub-1 rhizoplanic isolate R1 was Gram negative, non-spore forming rod and the cultural, morphological, physiological and biochemical characters like oxidation and fermentation of glucose and lactose, catalase and oxidase tests, indole production, methyl red, Voges Proskauer, nitrate reduction test etc. matched with the phenotypic characters of Enterobacter [8,9]. Thus, the phenotypic and 16S rDNA phylogenetic results of R1 were in agreement with the characters of Enterobacter sp. of the Family Enterobacteriaceae, order Enterobacteriales and class Gammaproteobacteria [9,22]. Nevertheless, Enterobacter spp. are recorded as commonly occurring rhizobacteria of rice and isolated from rhizoplane of rice cv. BR29 in Bangladesh [7].

The rhizoplanic R1 was an efficient $\mathrm{P}$ solubilizer i.e. maximum $\mathrm{P}(574.7 \mu \mathrm{g} / \mathrm{ml})$ released from Ca-phosphate along with lowering of medium $\mathrm{pH} 4.04$ (Fig. 1) which would be due to acidification and corroborated the propositions of other researchers [1,23], although acidification is not the only phosphate solubilization mechanism of PGPR. P mineralization the by R1 $(574.7 \mu \mathrm{g} / \mathrm{ml})$ was, however, higher than the rice rhizoplanic Acinetobacter sp. BR-25 and Klebsiella sp. BR-15 which released $524 \mu \mathrm{g} / \mathrm{ml}$ and $395 \mu \mathrm{g} / \mathrm{ml} \mathrm{P}$ with PSI 6.7 and 4.8, respectively, and intensely colonized on the root surfaces of seedlings of bacteria challenged rice seeds [7]. Zinc phosphate solubilization $(434.1 \mu \mathrm{g} / \mathrm{ml}, \mathrm{pH} 5.1)$ by $\mathrm{R} 1$ supported the observation in E. cloacae strain ZSB14 which is an important biogeochemical function in soil [24]. Phytase production by R1 and sodium phytate $(84.52 \mu \mathrm{g} / \mathrm{ml}$ at $\mathrm{pH}$ 4.51) solubilization (Fig. 2) conformed earlier reports [25]. Apart from $\mathrm{P}$ solubilization, R1 produced indole, siderophore and ammonia which corroborated the characters of another rice rhizospheric Enterobacter sp. (M183) [26] and tolerated 9\% $\mathrm{NaCl}$. Therefore, the organism can be used as a halotolerant PGPB for maintaining soil health to sustain rice production in saline ecologies. 
Mineralization of rock phosphates and slag by R1 (Fig. 3) proved its capability to mineralize different insoluble $\mathrm{P}$ in soil which would enrich nutrients for the plants [1]. Conversion rate of phosphates by R1 (Table 2) was maximum $(82.58 \% \mathrm{P})$ for Gafsa rock in $72 \mathrm{~h}$ and minimum $(26.08 \%)$ in $72 \mathrm{~h}$ from Tenesse rock which supported Erwinia sp. and Azotobacter sp. that solubilized $76.6 \%$ and $96.7 \%$ Tunisian phosphorite (TP), respectively. However, phosphate concentration, acidity $(\mathrm{pH})$, particle size of TP and microbial consumption affect $\mathrm{P}$ accumulation in the medium [27]. Mineralization of various phosphatic compounds by R1 corroborated the P solubilization by different rhizoplanic bacteria viz. Enterobacter, Pseudomonas, Pantoea spp. etc. [7].

The $p q q \mathrm{C}$ gene in Enterobacter sp. R1 (Fig. 4) confirmed that it was primed for $\mathrm{P}$ metabolism as $p q q \mathrm{C}$ is the determinant of P-solubilization [28] and an important marker to assess $\mathrm{P}$ metabolism and diversity in bacteria viz. Pseudomonas spp. [17].

Acid phosphatase $(22.25 \mathrm{U} / \mathrm{ml})$ and alkaline phosphatase $(76.37 \mathrm{U} / \mathrm{ml})$ activities of $\mathrm{R} 1$ also proved intrinsic phosphate solubilizing efficiency of the bacterium and supported the proposition of different other bacteria $[29,30]$.

Enterobacter sp. R1 produced lactic (Rf 0.89) and citric (Rf 0.62) acids (Fig. 5) which supported earlier observation [19]. All acids could not be resolved in TLC which suggests that metabolism of different OAs was variable and some of them were lower than detection limit by TLC. HPLC revealed tartaric, malic, acetic, succinic, lactic and citric acids in culture broth of R1 (Fig. 6) which would affect P- solubilization by the organism and conformed to OA production by $\mathrm{P}$ solubilizing Pseudomonas sp. [31].

The preservative combination of citric acid $(0.1 \%)$, sodium benzoate $(0.2 \%)$, glycerol $(0.1 \%)$ sustained the organism up to $100 \mathrm{~d}$ attaining $5.22 \times 10^{7} \mathrm{cfu} / \mathrm{ml}$ (Table 3) which suggests that antistress functions of the supplements favoured R1. The results proved that the preservatives would help for product development and shelf life enhancement of the bacteria and supported the observations of shelf life enhancement of rice by rhizospheric $P$. fluorescens and B. pyrrocinia formulations [32,33].

Enterobacter sp. (R1) treated Naveen seedlings increased root length $(66.67 \%)$, root number $(40 \%)$ and shoot length (28.81\%), fr.wt. and dr. wt. over control after 8d growth in laboratory (Fig. 7, Table 4). R1 (T2) increased root length of rice seedling by $10.43 \%$ over commercial bacteria (T3). Enhancement of fr. and dr. wt. of roots and shoot lengths were significant at p $<0.05$ and were maximum in rice seedlings treated with Enterobacter $\mathrm{sp}$. R1 (T2) (Fig. 8, Table 5) which supported the positive effects on shoot length and root hair formation in PGPB treated rice seeds [34].

Enterobacter sp. R1 treatment supported significant growth enhancement in pot and field (Table 6, 7, 8, Fig. 9, $10,11)$ which proved it to be a promising plant growth promoter. Combination of R1 and fertilizer exhibited maximum increase in height, root length, fr. and dr. wt. of root and shoot of rice plant (Table 7,8$)$ alike in wheat [35]. Grain yield and chlorophyll content of leaves in both rabi and kharif seasons also increased significantly ( $p$ $<0.001$ ) in the bacteria treated plants (Table 7,8). More grain yield of rice by R1 corroborated yield increase by Burkholderia sp. (BRRh-4) and P. aeruginosa (BRRh-5) treated rice seedling root followed by $50 \%$ recommended NPK [36], as well as, more height and tiller number increase of rice seedlings [37]. Inoculation of rhizospheric/rhizoplanic P-solubilizing bacteria in maize with rock phosphate also increased shoot (21\%) and root $(11 \%)$ length, shoot fr. $(42 \%)$ and dr. (24\%) wt., root fr. (59\%) and dr. (35\%) wt. and chlorophyll content $(32 \%)$ in maize [38]. Like R1, B. subtilis also increased grain yield of rice by 1.66 and 1.55 fold in pot and field environment [39]. The results of the study proved that Enterobacter sp. R1 can be used as an efficient biofertilizer in normal and saline environments for improvement/sustenance of rice growth and production.

\section{CONCLUSION}

Application of Enterobacter sp. R1 with N, K and half P fertilizers produced higher grains in pot and field conditions. The organism was halotolerant and can be exploited for maintenance of soil health and nutrition in saline environment and plant growth promotion. Cloning of the phosphate solubilizing gene in suitable strains would be a promising approach to generate efficient P-solubilizers.

\section{ACKNOWLEDGEMENT}

The authors are thankful to ICAR, New Delhi for the financial support through the 'Application of Microorganisms in Agriculture and Allied Sectors (AMAAS) project' "Nutrient management, PGPR and biocontrol".

\section{REFERENCES}

[1] Dash, N. and T.K. Dangar, 2017. Perspectives of phosphate solubilizing microbes for plant growth promotion, especially rice - A Review. International Journal of Biochemistry Research \& Review, 18(3): 1-16. 
Nilima Dash, Tushar Kanti Dangar., 2019. Phosphate mineralization by a rice (Oryza sativa L.) rhizoplanic Enterobacter sp./American-Eurasian Journal of Sustainable Agriculture. 13(4): 1-17.DOI: 10.22587/aejsa.2019.13.4.1

[2] Chang, C.H. and S.S. Yang, 2009. Thermo-tolerant phosphate-solubilizing microbes for multifunctional biofertilizer preparation. Bioresource Technology, 100(4): 1648-1658.

[3] Alam, M.S., N.M. Talukder, M.T. Islam and A. Rahman, 2008. Rhizoplane bacteria as phosphate solubilizing agent on phosphorus nutrition of rice. Bangladesh Journal of Agricultural Sciences, 35(2): 181-188.

[4] Krishnaraj, P.U. and S. Dahale, 2014. Mineral Phosphate Solubilization: Concepts and Prospects in Sustainable Agriculture. Proceedings of the Indian National Science Academy, 80(2): 389-405.

[5] Kim, C.H., S.H. Han, K.Y. Kim, B.H. Cho, Y.H. Kim, B.S. Koo and Y.C. Kim, 2003. Cloning and expression of pyrroloquinoline quinone (PQQ) genes from a phosphate solubilizing bacterium Enterobacter intermedium. Current Microbiology, 47(6): 457-461.

[6] Hashidoko, Y., T. Hasegawa, E. Purnomo, M. Tada, S.H. Limin, M. Osaki and S. Tahara, 2004. Neutral rhizoplane $\mathrm{pH}$ of local rice and some predominant tree species in South and Central Kalimantans: A possible strategy of plant adaptation to acidic-soil. TROPICS, 14(2): 139-147.

[7] Islam, Md,T., A, Deora, Y, Hashidoko, A. Rahmana, T. Itoa and S. Tahara, 2007. Isolation and identification of potential phosphate solubilizing bacteria from the rhizoplane of Oryza sativa L. cv. BR29 of Bangladesh. Zeitschriftfür Naturforschung, 62(1-2): 103-110.

[8] Smibert, R.M. and N.R. Krieg, 1995. Phenotypic characterization. In: Gerhardt P, Murray RGE, Wood W, Krieg E (eds) Methods for general and molecular bacteriology. American Society for Microbiology, Washington pp. 607-654.

[9] Brenner, D.J., N.R. Krieg and J.T. Staley, 2005. Volume Two. The Proteobacteria. Part A. Introductory Essays. In G.M. Garrity (ed.), Bergey’s Manual of Systematic Bacteriology, Second Edition. SpringerVerlag, New York: [i]-xxvi, 1-304.

[10] Ponmurugan, P. and C. Gopi, 2006. Distribution pattern and screening of phosphate solubilising bacteria isolated from different food and forage crops. Agronomy Journal, 5(4): 600-604.

[11] Olsen, S.R., C.V. Cole, F.S. Watanabe and L.A. Dean, 1954. Estimation of available phosphorus in soil by extraction with sodium bicarbonate. USDA Circ. 939. U.S. Government Printing Office, Washington, D.C.

[12] Kerovuo, J., M. Lauraeus, P. Nurminen, N. Kalkinen and J. Apajalahti, 1998. Isolation, characterization, molecular gene cloning, and sequencing of a novel phytase from Bacillus subtilis. Applied and Environmental Microbiology, 64(6): 2079-2085.

[13] Bric, J.M., R.M. Bostock and S.E. Silverstone, 1991. Rapid in situ assay for indoleacetic-acid production by bacteria immobilized on a nitrocellulose membrane. Applied and Environmental Microbiology, 57(2): 535-538.

[14] Schwyn, B. and J.B. Neilands, 1987. Universal chemical assay for the detection and determination of siderophore. Analytical Biochemistry, 160(1): 47-56.

[15] Reddy, B.P., K.R.N. Reddy, R.M. Subba and K.S. Rao, 2008. Efficacy of antimicrobial metabolites of Pseudomonas fluorescens against rice fungal pathogens. Current Trends in Biotechnology and Pharmacy, 2(1): 178-182.

[16] Cappuccino, J.G. and N. Sherman, 1992. Biochemical activities of microorganisms. In: Microbiology, A Laboratory Manual, The Benjamin/Cummings Publishing Co., California, USA.

[17] Meyer, J.B., M. Frapolli, C. Kee and M. Maurhofer, 2011. Pyrroloquinoline quinone biosynthesis gene pqqC, a novel molecular marker for studying the phylogeny and diversity of phosphate-solubilizing Pseudomonads. Applied and Environmental Microbiology, 77(20): 7345-7354.

[18] Tabatabai, M.A. and J.M. Bremner, 1969. Use of p-nitrophenol phosphate for the assay of soil phosphatase activity. Soil Biology and Biochemistry, 1(4): 301-307.

[19] Chaffai, R., T. Ali and E. Ferjani, 2006. A comparative study on the organic acid content and exudation in maize (Zea mays L.) seedlings under conditions of copper and cadmium stress. Asian Journal of Plant Sciences, 5(4): 598-606.

[20] Rashid, M., S. Khalil, N. Ayub, S. Alam and F. Latif, 2004. Organic acids production and phosphate solubilization by phosphate solubilizing microorganisms (PSM) under in vitro conditions. Pakistan Journal of Biological Sciences, 7(2): 187-196.

[21] Arnon, D.I., 1949. Copper enzymes in isolated chloroplasts, polyphenoloxidase in Beta vulgaris. Plant Physiology, 24(1): 1-15.

[22] Garrity, G.M., M. Winters and D.B. Searles, 2001. Taxonomic outline of the prokaryotic genera. Bergey's Manual of Systematic Bacteriology, 2nd Edition. Release 1.0: 1-39, Springer, New York.

[23] Malboobi, M.A., P. Owlia, M. Behbahani, E. Sarokhani, S. Moradi, B. Yakhchali, A. Deljou and K.M. Heravi, 2009. Solubilization of organic and inorganic phosphates by three highly efficient soil bacterial isolates. World Journal of Microbiology and Biotechnology, 25: 1471-1477. 
Nilima Dash, Tushar Kanti Dangar., 2019. Phosphate mineralization by a rice (Oryza sativa L.) rhizoplanic Enterobacter sp./American-Eurasian Journal of Sustainable Agriculture. 13(4): 1-17.DOI: 10.22587/aejsa.2019.13.4.1

[24] Krithika, S., G. Prasad and D. Balachandar, 2016. Zinc solubilizing potential of Enterobacter cloacae strain ZSB14 in three different semi-arid tropical soils. International Journal of Plant \& Soil Science, 11(2): $1-12$.

[25] Singh, B. and T. Satyanarayana, 2011. Microbial phytases in phosphorus acquisition and plant growth promotion. Physiology and Molecular Biology of Plants, 17(2): 93-103.

[26] Bakhshandeh, E., H. Rahimian, H. Pirdashti and G. Nematzadeh, 2014. Phosphate solubilization potential and modeling of stress tolerance of rhizobacteria from rice paddy soil in northern Iran. World Journal of Microbiology and Biotechnology, 30(9): 2437-2447.

[27] Ivanova, R., D. Bojinova and K. Nedialkova, 2006. Rock phosphate solubilization by soil bacteria. Journal of the University of Chemical Technology and Metallurgy, 41(3): 297-302.

[28] Sashidhar, B. and A.R. Podile, 2010. Mineral phosphate solubilization by rhizosphere bacteria and scope for manipulation of the direct oxidation pathway involving glucose dehydrogenase. Journal of Applied Microbiology, 109(1): 1-12.

[29] Prasanna, A., V. Deepa, M.P. Balakrishna, M. Deecaraman, R. Sridhar and P. Dhandapani, 2011. Insoluble phosphate solubilization by bacterial strains isolated from rice rhizosphere soils from Southern India. International Journal of Soil Science, 6(2): 134-141.

[30] Behera, B.C., H. Yadav, S.K. Singh, R.R. Mishra, B.K. Sethi, S.K. Dutta and H.N. Thatoi, 2017. Phosphate solubilization and acid phosphatase activity of Serratia sp. isolated from mangrove soil of Mahanadi river delta, Odisha, India. Journal of Genetic Engineering and Biotechnology, 15(1): 169-178.

[31]Chen, W., F. Yang, L. Zhang and J. Wang, 2015. Organic acid secretion and phosphate solubilizing efficiency of Pseudomonas sp. PSB12: Effects of phosphorus forms and carbon sources. Geomicrobiology Journal, 33: 870-877.

[32] Yadav, A., S. Dhull, A. Sehrawat and S. Suneja, 2017. Growth, survival and shelf life enhancement of phosphate solubilizing bacterial liquid inoculants formulations with polymeric additives. The Bioscan, 12(1): 113-116.

[33] Arriel-Elias, M.T., M.I.S. Oliveira, V.L. Silva-Lobo, M.C.C. Filippi, A.H. Babana, E.C. Conceicao and M.V. de CB Cortes, 2018. Shelf life enhancement of plant growth promoting rhizobacteria using a simple formulation screening method. African Journal of Microbiology Research, 12(5): 115-126.

[34] Mia, M.A.B. and Z.H. Shamsuddin, 2010. Nitrogen fixation and transportation by Rhizobacteria: A scenario of rice and banana. International Journal of Botany, 6(3): 235-242.

[35] Kumar, V., R.K. Behl and N. Narula, 2001. Establishment of phosphate-solubilizing strains of Azotobacter chroococcum in the rhizosphere and their effect on wheat cultivars under green house conditions. Microbiological Research, 156(1): 87-93.

[36] Khan, M.M.A., E. Haque, N.C. Paul, M.A. Khaleque, S.M.S. Al-Garni, M. Rahmanand, M.T. Islam, 2017. Enhancement of growth and grain yield of rice in nutrient deficient soils by rice probiotic bacteria. Rice Science, 24(5): 264-273.

[37] Sarkar, A., T. Islam, G.C. Biswas, M.S. Alam, M. Hossain and N.M. Talukder, 2012. Screening for phosphate solubilizing bacteria inhabiting the rhizoplane of rice grown in acidic soil in Bangladesh. Acta Microbiologica etImmunologica Hungarica, 59(2): 199-213.

[38] Manzoor, M., M. KaleemAbbasi and T. Sultan, 2017. Isolation of phosphate solubilizing bacteria from maize rhizosphere and their potential for rock phosphate solubilization-mineralization and plant growth promotion. Geomicrobiology Journal, 34(1): 81-95.

[39] Trivedi, P., B. Kumar, A. Pandey and L.M.S. Palni, 2003. Growth promotion of rice by phosphate solubilizing bioinoculants in a Himalayan location. In: Velazquez E, Rodriguez-Barrueco C, eds. Plant and soil. Developments in plant and soil sciences. First international meeting on microbial phosphate solubilization. Salamanca, Spain. Heidelberg: Springer, 291-299. 